\title{
Practices of the Event
}

\author{
Thesis by: \\ Nicholas Waissbluth

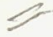 \\ Thesis Supervisor: \\ Michael Jemtrud
}

\begin{abstract}
A thesis submitted to the Faculty of Graduate Studies and Research in partial fulfillment of the requirements for the degree of

\section{Professional Masters of Architecture}

\author{
School of Architecture \\ Carleton University \\ Ottawa, Ontario \\ September 30, 2005 \\ (C) copyright 2005 \\ Nicholas Waissbluth
}




\begin{abstract}
What is the future of the contemporary city? Where does architecture play a role in the marking of "place" in this future condition? One idea is the temporal city, where time precedes our given identities, where the future is invisible and every action we do, as a citizen, visitor and participants always departs from the foreseeable identities. A city where architecture would not be understood as a formal object, but a generator to guide the city as a continual transforming environment. This paper is an exploration into this condition. To break away from the formal city that emerged from the twentieth century modernists, this paper explores the role of architecture in the formal and temporal boundaries of the city.
\end{abstract}


Table of Contents

Page

Abstract

ii

List of Illustrations

iv

List of Appendices

Practices of the Event $\quad 8$

i. Introduction $\cdot 8$

ii. Boundary - Place 11

iii. Fields of Play 21

iv. Conclusion 31

v. Design Proposal 33

$\begin{array}{ll}\text { Llanos del Solar } & 38\end{array}$

$\begin{array}{ll}\text { Bibliography } & 81\end{array}$ 


\section{List of Illustrations}

Figure 1.0: Santiago Growth Pattern.

Figure 1.1: Curauma, Chile. Housing.

Figure 1.2: Diagram; Urban Form

Figure 1.3: Soria y Mata, La Ciudad Lineal. Madrid, Spain.

Figure 1.4: Plan for Brasilia, Brazil (1958).

Figure 1.5: Aerial View: Brasilia, Brazil.

Figure 1.6: Brasilia Housing

Figure 1.7: Brasilia: Superquadra

Figure 1.8: Diagram; Elements of the City. Kevin Lynch

Figure 1.9: Decentralization

Figure 1.10: Suburban Development

Figure 1.11: Suburban Development

Figure 1.12: Downsview Park Competition Site.

Figure 1.13: Downsview Park Design Entry.

Figure 1.14: English Garden. Sir Humphrey Repton.

Figure 1.15: Program Density Diagram.

Figure 1.16: Program Density Diagram.

Figure 1.17: Downsview Park Growth Pattern.

Figure 2.0: Llanos del Solar

Figure 2.2: Chacabuco Region.

Figure 2.1: Infrastructure for Gran Santiago 
Figure 2.3: Phase 2 Concept Diagram

Figure 2.4: Existing Flow of Movement.

Figure 2.5: New Growth Corridors.

Figure 2.6: New Growth Corridors.

Figure 2.7: Clustered Growth Pattern.

Figure 2.8: Residential Pattern.

Figure 2.9: High Density Patterns.

Figure 2.10: Wraps. Plan.

Figure 2.11: Building Envelope. Exploded View.

Figure 2.12: Building Envelope. Section.

Figure 2.13: Growth of a high-density neighborhood.

Figure 2.14: Layers of high-density neighborhood.

Figure 3.0: Llanos del Solar, Chile. Aerial View.

Figure 3.1: Chacabuco Region.

Figure 3.2: Infrastructure for Gran Santiago.

Figure 3.3: Infrastructure for Gran Santiago.

Figure 3.4: Flexible/ Non Flexible Growth.

Figure 4.1: Curitiba Bus Station.

Figure 4.2: Agache Plan for Curitiba, 1941.

Figure 4.3: Agache Plan for Curitiba, 1941.

Figure 4.4: Spontaneous Growth Diagram. 
Figure 4.5: Planned Growth Diagram.

Figure 4.6: Curitiba Arterial Growth Corridors.

Figure 4.7: Curitiba Land-use.

Figure 4.8: Curitiba Road Infrastructure.

Figure 4.9: Section, Curitiba Growth Corridor.

Figure 4.10: Plan, Curitiba Growth Corridor.

Figure 4.11: Detail Plan of Bus Station.

Figure 4.12: Tube Bus Station.

Figure 4.13: Tube Bus Station.

Figure 4.14 Tube Bus Station.

Figure 4.15: Tube Bus Station.

Figure 4.16: Curitiba Transportation Map (2002). 
List of Appendices

\section{Page}

\section{Appendix I}

Design Proposal. Requirements.

60

Appendix II

Case Study. Curitiba, Brazil

66 


\section{Introduction}

What is the future of the contemporary city? Where does architecture play a role in the marking of "place" in this future condition? One idea is the temporal city, where time precedes our given identities, where the future is invisible and every action we do, as a citizen, visitor and participants always departs from the foreseeable identities. A city where architecture would not be understood as a formal object, but a generator to guide the city as a continual transforming environment. This paper is an exploration into this condition. It is an exploration in the role of architecture in the territorialization of space, through the relationship between formal and temporal boundary conditions.

During the last several decades, it is evident that the role of architecture in the identity of place has been affected. Prior to the twentieth century, a city was understood as being structured by its formal arrangements and coherent urban types of space such as; the street, the square, and the boulevard. This structure however, is not as evident today. The organization and structure of the contemporary city is becoming increasingly more difficult to define. There are urban theories and popularized "movements" that are guiding the growth of many cities today however, in the end, every city is struggling with its own historical and present situation to find a path for the future. This project therefore, is not to define the "City" or "Architecture" today, but to investigate the role of architecture in the territorialization of space - where can architecture move beyond the purely formal dimension.

To begin, I shall consider the term "boundary" in its traditional sense - a territorial architecture that separates one entity from another by walls of permanence. In the context of a city, this condition exists when places are defined by the formal geometry of objects. 
In elaborating this condition however, the scope in how we classify architectural boundaries will broaden. They will no longer only be places defined by formal relationships, but are all objects. This condition leads to the materialization of space and the dematerialization of architecture. ${ }^{1}$ This is the effect of the formal city, as in the case of Brasilia, Brazil; achieving the ideals of the modernists, "making no distinction between architecture and urbanism, landscaping and plastics arts." To move beyond the formal territories, the investigation will shift away from the formal and explore how the event can be an active element in territoriality. There are events, such as a parade or a concert in an open field that can create a sense of place, but it is the theatrical unplanned events in our everydayness (on the sidewalks, at our homes, in the office) that I refer to. It is the social spatiality of the city composed of complex "layering of the time-space rhythms of multiple space time relations, some of which narrowly confined to a particular part of the city, others of which spread across many places near and far from the city."3 This is the manifestation of the milieu, where the practices of the event construct a temporal boundary condition, that I shall call field of play. The overlapping of the formal and the temporal is, I suggest, the territorialization of space where architecture is no longer an object, but a system in play within the urbanization of the city.

Territorialization is the act of continuous ratification and transforming from one state to another. "Place" therefore is not only marked by the symbolic monuments of the city, but is also potentially everywhere; it is a state of change.

\footnotetext{
1 The two-dimensional surface (facade) contains and projects the identity of the place.

2 Lauro Vacalcanti. "When Brazil was Modern: From Rio de Janeiro to Brasilia." Cruelty and

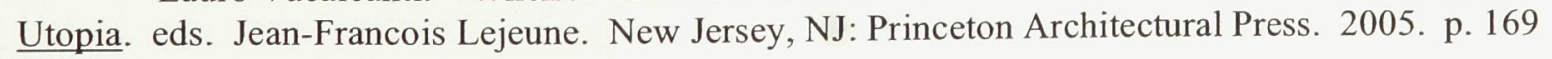

3 Patsy Healy. "On Creating the City as a Collective Resource." Urban Studies, Vol. 39, No. 10, 1777-1792, 2002. p.1780
} 
The goal of this dual investigation of the temporal and formal markings of place is to suggest that architecture exists in both. In moving beyond the purely formal city, identity must be understood as always becoming, and never concrete. The architecture of the city must reflect this condition by not only informing citizens, but allowing for unexpected space and interactions to occur. We as citizens of cities, are always changing using new technologies and forms of communication. If "place" remains only structured by formal elements, we are rejecting the very act of this change.

Beyond this investigation of "place," this paper will be completed in a design application. Using a site chosen outside Santiago, Chile as a contextual basis for this investigation, it is the goal of this last section to demonstrate at an architectural standpoint, how architecture can become a generator in defying the built environment.

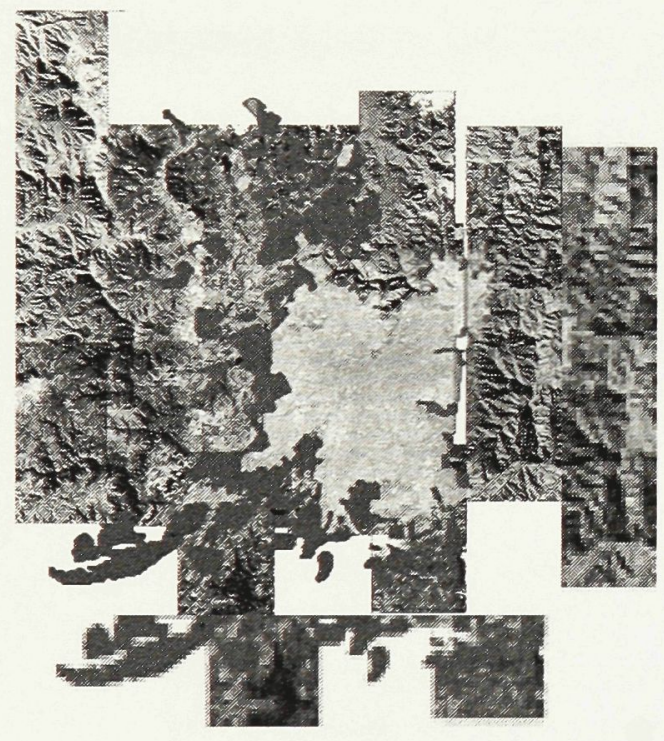

Figure 1.0: Santiago Growth Pattern: White: 2005 - Red : 2025

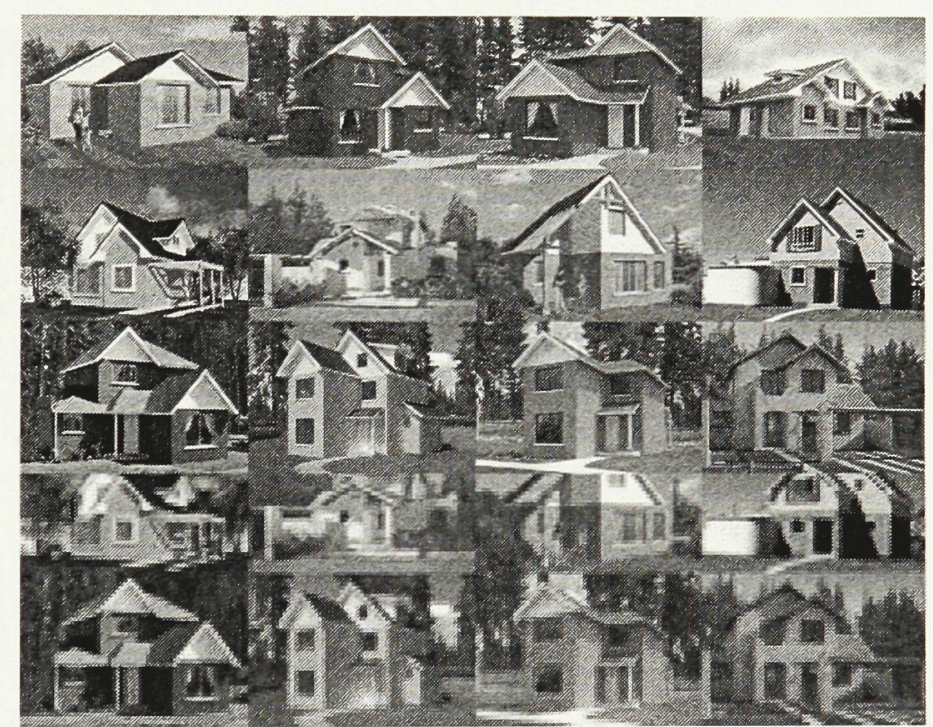

Figure 1.1: Curauma, Chile. Typical Housing development in Chile. (Source: http://www.curauma.cl) 


\section{Boundary - Territory - Place}

If we look at the term boundary in a purely objective manner, we will find that boundaries deal with three categories. The first being as an extremity, the second as a line and lastly, boundary as a limit. The first category is defined as the line or plane indicating the limit or extent of something, followed by a line determining the limits of an area, and third category defined as the greatest possible degree of something. ${ }^{4}$ Boundaries by definition therefore, must exist within the paradigm of limits. A boundary can not exist if there is no limit; it can only exist if there is something for it to differentiate itself from.

Cities are filled with boundaries - both formal and temporal. The first defined as areas drawn out by the placement of buildings, streets, walls and fences, and the second defined by the events and flows that inhabit the formal. In the formal, boundaries are; physical, may have an interiority (internal structure or environment) and they have qualitative properties that shape city life and various types of urban space. The formal markings and boundaries are an integral part of any city - it is what orientates us while we travel, it is what represents our communities, cultures and holds the history of the city. Joseph Rykwert explains:

Points of orientation are essential for any urban or rural living, Without them a citizen cannot "read," let alone "understand" his home. A distinctive and legible environment not only offers security but also heightens the potential depth and intensity of human experience. ${ }^{5}$

\footnotetext{
$4 \quad$ "Boundary." Merriam-Webster's Collegiate Dictionary. 1980

5 Joseph Rykwert. The Seduction of Place. The History and Future of the City. Oxford: England. Oxford University Press. 2000. p. 132-133
} 


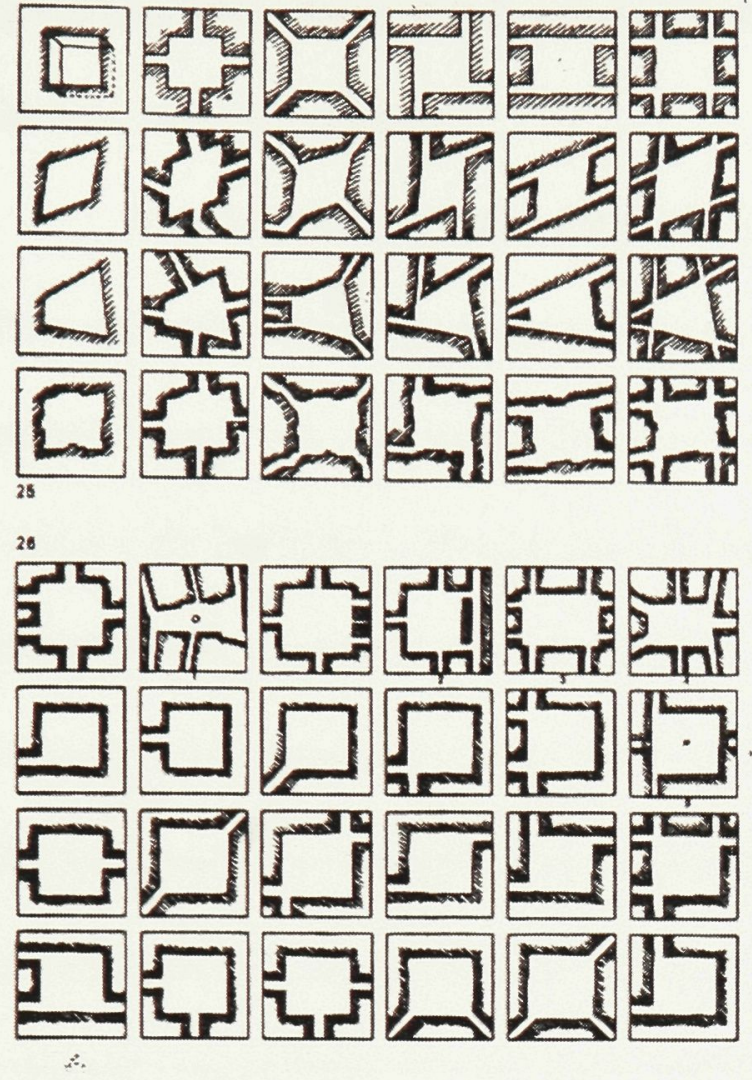

Figure 1.2: Diagram; Urban Forms. Prior to the twentieth century, urban space was understood as being as being the negative condition of the formal constructions. (Source: Aarhus School of Architecture. $<\underline{\text { http: } / / \text { aarch.dk } />\text { ) }}$

Prior to the twentieth century, the formal boundaries of the city were the structures of urban space. The square, plaza, and courtyard were shaped by the form of the city. ${ }^{6}$ In other words, the marking of place was defined by the architectural relationships of a given area. The industrial revolution in the late nineteenth century however, began a transition in the conception of urban form. These changes led to the spatial explorations of the early modernists that in turn inverted the traditional sense. Modernist space presented a new universal sense of space, "in which architecture appeared free-standing and disconnected...inverting the traditional relationship between

\footnotetext{
Graham Livesey. Passages: Explorations of the Contemporary City. Calgary, Alb.: University of Calgary Press, 2004.p. 3
} 
space and urban form.", It is a territorialization of space structured by the placement of the free standing objects.

Viewing the industrial mononucleated city as a chaotic and dysfunctional system, the twentieth century modernists envisioned what Lewis Mumford refers to the polynucleated city structure. ${ }^{8}$ The most influential of these visions is the theory of the Linear City by Soria y Mata in the late nineteenth century that went on to influence architects such as; Le Corbusier (specifically plans for Rio de Janeiro and Algiers); Tony Garnier's Industrial City, and Lucio Costa's plan for Brasilia. ${ }^{9}$ The Linear city is a system theory based on movement intertwined into a network of neighborhoods and communities bound together by travel. It is a plan with a tightly defined section, but infinitely expandable. At the centre are the arterial railways, and on either side sits a row of two hundred meter blocks of housing. Beyond them, sits a belt of agricultural land four kilometres wide. In plan, it is a city structure to facilitate movement from one place to another. "The key factor in urban living is not distance but travel time."10 Mumford describes the Linear City as a success in reviewing the industrial city. It has the ability to provide the urban qualities of the metropolis, "without the tiresome instabilities, its capital frozen into unprofitable utilities, and its land values congealed at levels that stand in the way of effective adaption to new needs." ${ }^{11}$ Soria y Mata applied this theory into the

$7 \quad$ Ibid. p. 4

8 Lewis Mumford. "What Is a City?" The City Reader, eds. Richard T. Legates, Frederic Stout. (New York, NY: Routledge, 1996) 92-96

9 Joseph Rykwert. The Seduction of Place. The History and Future of the City. Oxford: England. Oxford University Press. 2000. p. 98

10 Lewis Mumford. The City in History: Its Origins, Its Transformations, and Its Prospects. New York, NY: Harcourt, Brace \& World, 1961. p.506.

11 Lewis Mumford. "What Is a City?" The City Reader, eds. Richard T. Legates, Frederic Stout. (New York, NY: Routledge, 1996) 93 
Ciudad Lineal for Madrid in 1894. Though never fully built, it was a demonstration of the potential of zoning a city into fragments along a central flow of transportation. ${ }^{12}$

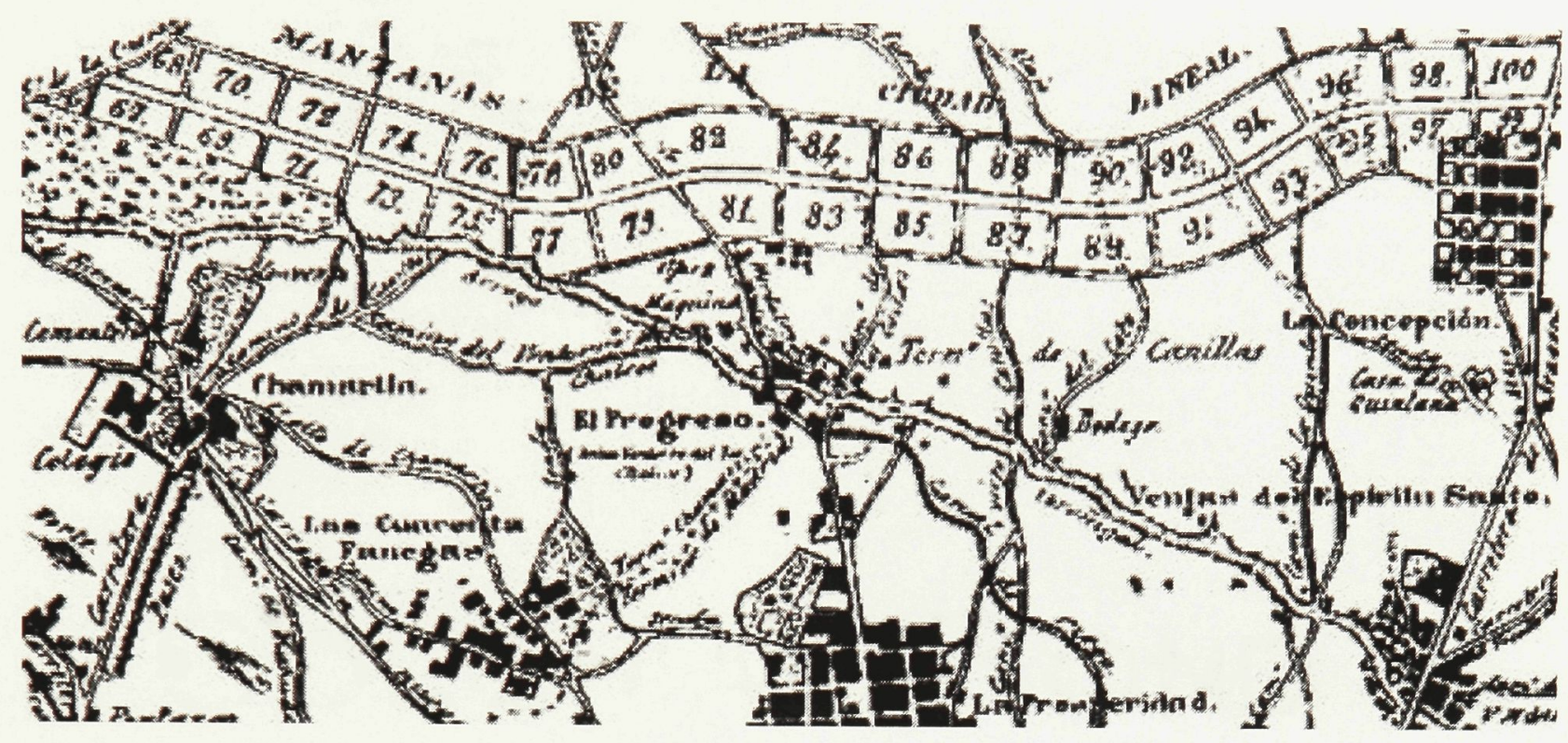

Figure 1.3: Soria y Mata, La Ciudad Lineal. Madrid, Spain.

(Source: Kosmograph Industries $<$ http://www.kosmograph.com/urbanism/industriale/ industriale $\bmod 4$.htm $>$ )

In the twentieth century, no other city has embraced the ideals of Soria and the shift in the marking of place other than the city of Brasilia. The bird-shaped master plan was conceived by Lucio Costa and Oscar Niemeyer in 1958, and became a a success by the modernist as a city that broke away from the traditional and reinterpreted how we perceive a city. The plan is composed of two bisecting axes: the striated wings of the bird lay out "live and leisure" sectors, and the the body of the bird is where the "work" sector is located. The body, composed of the parliamentary complexes, administrative buildings and civic monuments is the symbolic figure of the city as well as the country. The plan does not consider citizens or visitors, it is only to be read as an object of symbolism. The

\footnotetext{
The proposal for Madrid was only realized in short form - only 5 kilometres of the proposed scheme was built. The proposed plan was to run from Madrid to St. Petersburg.
} 
buildings "stand like sculptures, linked only by lines of force and tension like a neoplasticist composition."13

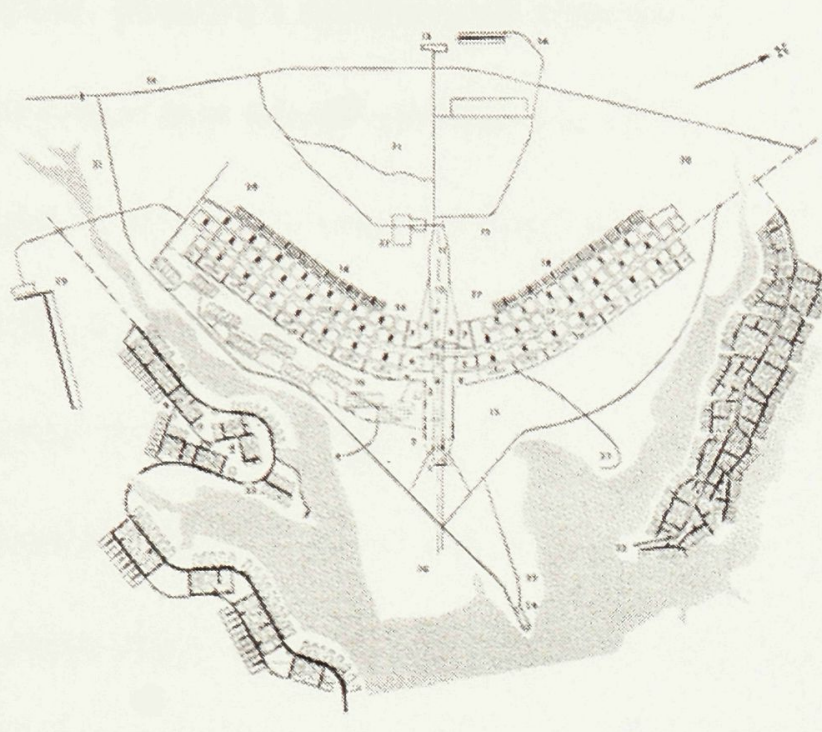

Figure 1.4: Plan for Brasilia, Brazil (1958).

(Source: Epstein, David. Brasilia, Plan and Reality. Berkeley, California: University of California Press. 1973. (insert map)

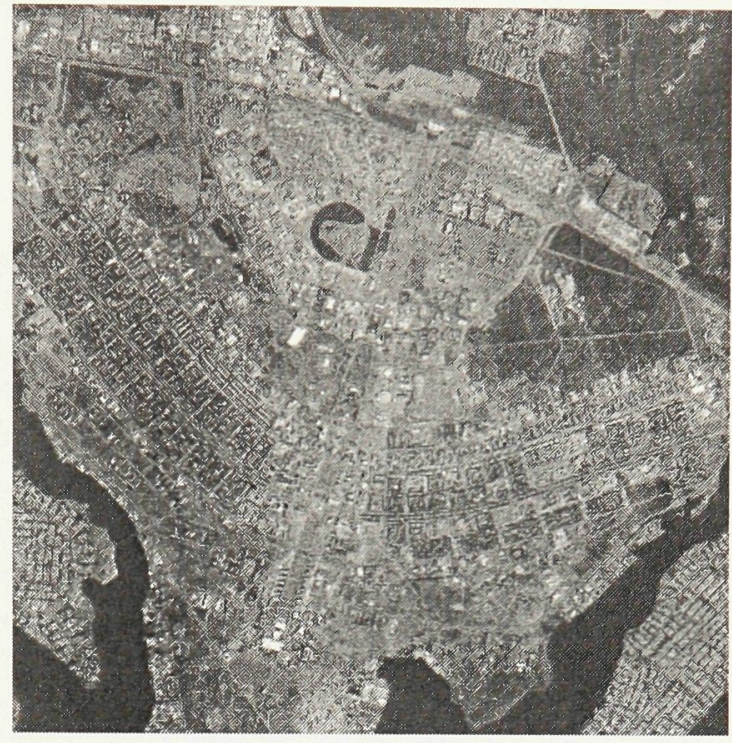

Figure 1.5: Brasilia, Aerial.

(Source: National Aeronautics and Space Administration. Remote Sensing Tutorial. $<$ http://rst.gsfc.nasa.gov/Sect4/Sect4 4.html $>$

Along the other axis (of the bird's wings), housing is laid out into two lots of sixty superquadras on either side of the main axis. Each superquadra is 240 by 240 metres and houses 2,500 inhabitants in box shaped dwellings varying between three and six stories and are mostly raised on pilotis. The uniform and strict guidelines of the housing quarters are a reflection of Lucio Costa's vision to keep a controlled environment that does not represent segregation or formal hierarchies. It is to maintain an even formal geometry.

This prevents the hateful differentiation of social classes [since]...all the families share the same life...Because of the inexistence of social class discrimination, the residents of a superquadra are forced as if into the sphere of a big family. ${ }^{14}$

13 Francisco Bullrich. New Directions in Latin American Architecture. New York, NY: G. Braziller. 1969. p.37

14 Joseph Rykwert. The Seduction of Place. The History and Future of the City. Oxford: England. Oxford University Press. 2000. p. 197. Referenced within book: Report on living conditions in the new capital from Brasilia (Journal of the Companhia Urbanizadora de Nova Capital do Brasil-NOVACAP), 
Every part of Brasilia was pre-conceived, leaving no room for any differences to occur. Brasilia's rigid master plan and its monumental architectural gestures, is a city structure that denies growth, and embraces the present. In comparison to the Ciudad Lineal, Brasilia's main strength lies in the central flow of movement and its ability to efficiently transport people from one physical place to another. However, in contrast to Soria's vision for Madrid which is based on mass transit and continual growth, Brasilia is planned for the private automobile and rejects growth. It is a materialized environment where place is marked by Oscar Niemeyer's symbolic buildings. As "Lucio Costa states in his report, basically the plan arose from the elementary gesture of one who marks and takes possession of a place." 15

1963, quoted in James Holston, The Modernist City, pp.20 ff. James Holston. The Modernist City. An Anthropological Critique of Brasilia. Chicago, IIl: U. of Illinois. 1989. p.20

15 Francisco Bullrich. New Directions in Latin American Architecture. New York, NY: G.

Braziller. 1969. p.36 


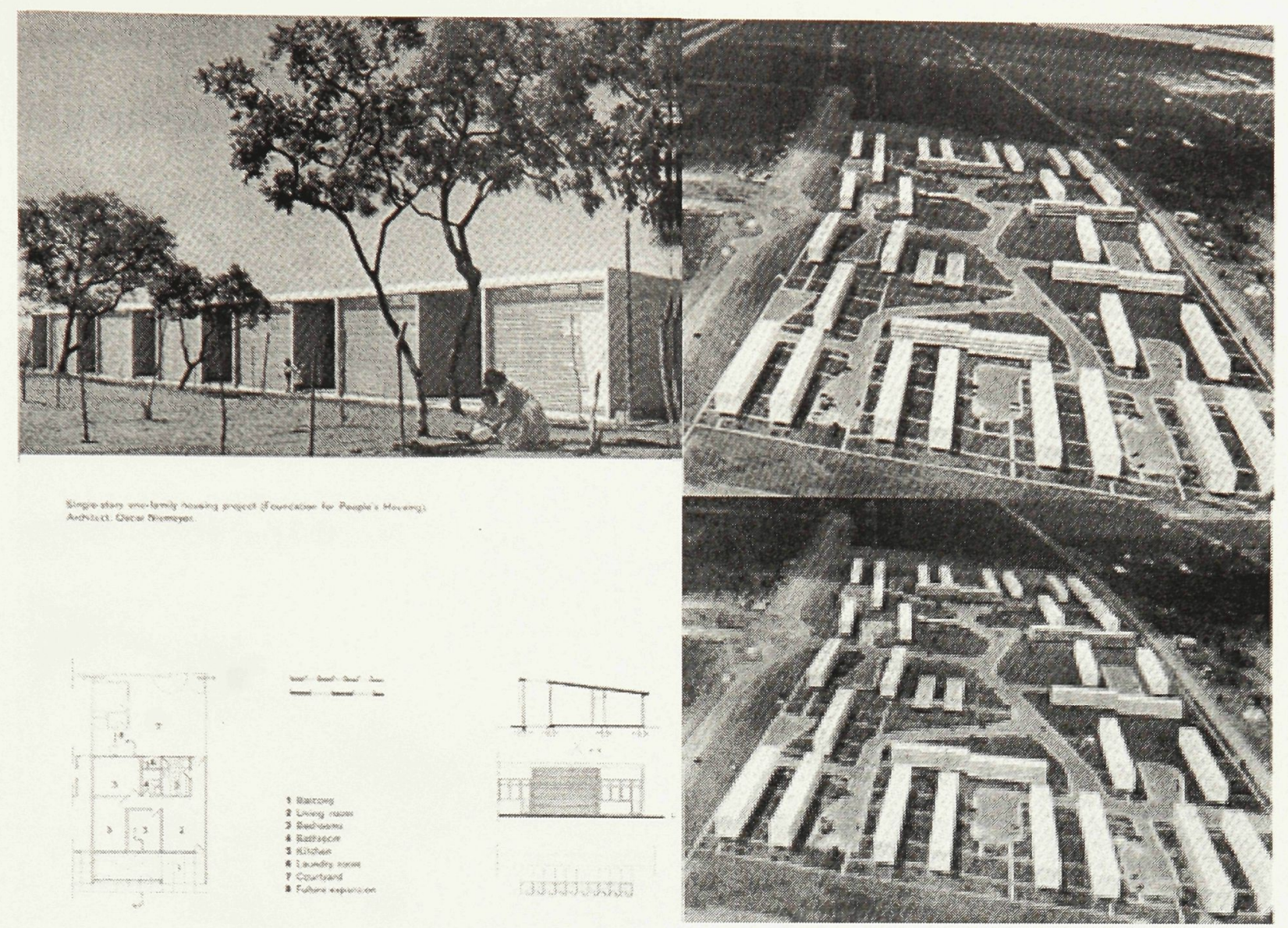

Figure 1.6: Brasilia, Housing.

(Source: James Holston. The Modernist City. An Anthropological Critique of Brasilia. Chicago, III: U. of Illinois. 1989. p.35)
Figure 1.7: Brasilia, Superquadra.

(Source: James Holston. The Modernist City. An Anthropological Critique of Brasilia. Chicago, IIl: U. of Illinois. 1989. p.18)

This shift in the role of architecture by Lucio Costa, Oscar Niemeyer and other modernists had a significant impact in the structure of cities. Architecture was no longer a coherent landscape of the city - but became all objects. Kevin Lynch outlines that the structure of a city became composed of five elements - the perceptual objects (paths, edges, districts, nodes and landmarks) to differentiate one place from another. ${ }^{16}$ After the reinterpretation of architecture and its role in the territorialization of space, Lynch notes that people will now perceive cities as consisting of formal elements and that it is the relationship between the formal and our perception of the formal where the sense of place

16 Kevin Lynch. The Image of the City. Cambridge: Mass., MIT Press. 2003. p.46 
is achieved. The paths of the city are the channels along which people move and observe their surroundings. More specifically, edges are the linear breaks of continuity such as walls or shorelines; districts are the sections of the city that people can enter "inside of" and that has an identifying character, nodes are the points or spots of the city with intensive concentrations (such as a junction and bus loop) and the landmarks of the city are the points of reference that one does not enter within but are simply external, physical objects with predefined images, usually historical. ${ }^{17}$

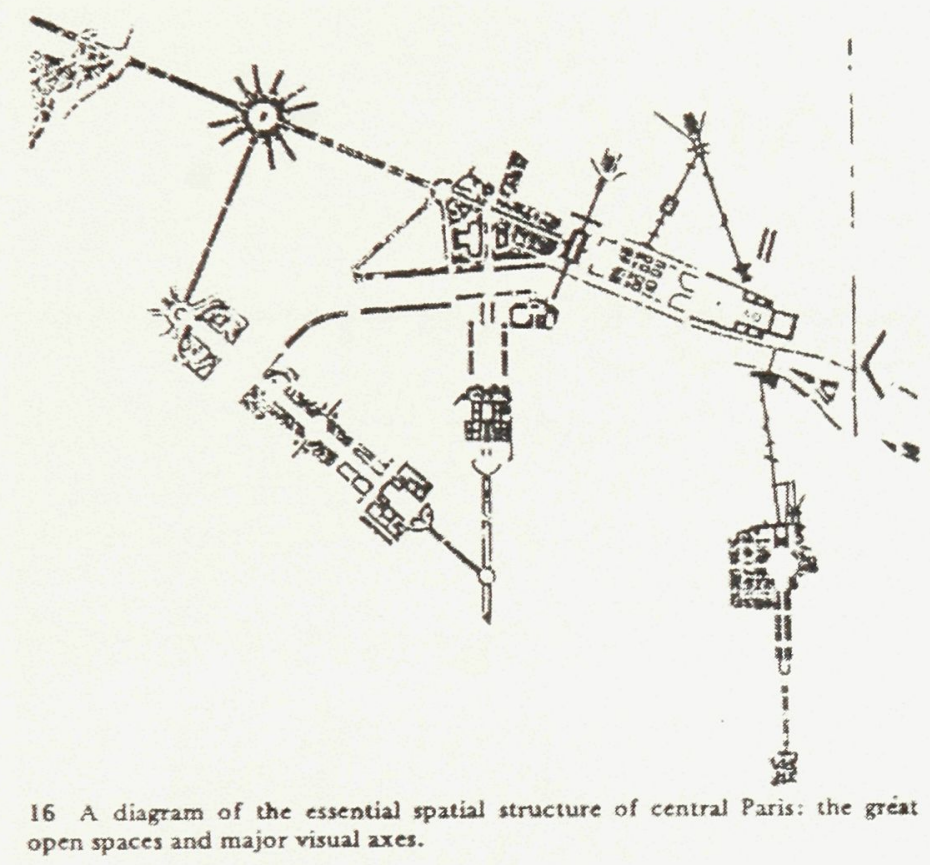

Figure 1.8: Diagram; Elements of the city. Kevin Lynch.(Source: Aarhus School of Architecture. $<\underline{\text { http: } / / \text { aarch.dk/ } />\text { ) }}$

Brasilia exemplifies the twentieth century city that is territorialized by formal elements. As Lucio Costa explains himself, the harsh and rigid guidelines that structure the city are to create an environment where no negations, conflicts or misunderstanding emerge. The identity of the city lies in its urban form, and territorial objects. In the post-

17 Ibid. 
war era, the modernist ideals continued and became a contributing factor in what is now known as urban sprawl or suburbanization.
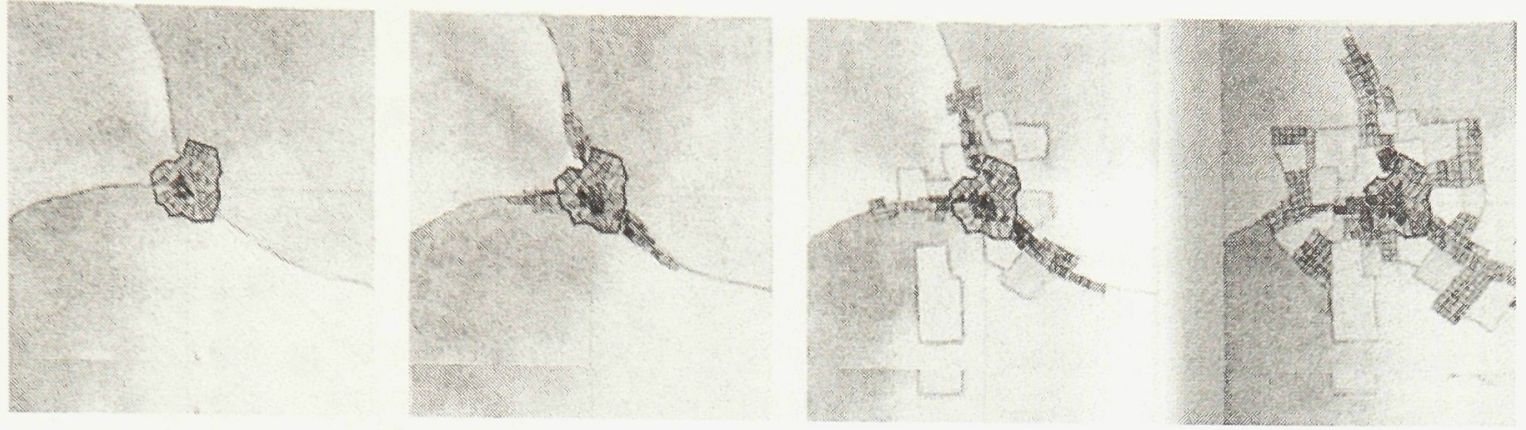

Figure 1.9: Decentralization.

(Source: Spiro Kostof. The City Shaped: Urban Patterns and Meanings Through History. London, England: Thames and Hudson. 1991. p. 119.)

This is the common condition of cities today with large, mainly residential communities being developed outside the historical city centres. There are many benefits in the growth in residential communities, however, there also exists risks in how the citizens understand their surroundings. Points of interests, monuments, nodes and landmarks are easily dwarfed by the vast landscape of these communities.

Such a city will therefore be short on places that might serve its inhabitants as landmarks, orientation guides, and "points of interest," or any other striking, easily identifiable features to use as meeting points. That is why even the most grasping developers will talk about "identity points," if only to allow a visitor to orient himself. ${ }^{18}$

In the situation of suburbanization, another kind of city has developed. It is a city structure influenced by the modernist shift in the role of architecture. It is a twodimensional structure where the identity of place is structure by points and "identity points." Thus, the historical notion of architecture has been lost. Urban sprawl is 'the domain where people drive around, experience familiar activities, and engender

\footnotetext{
18 Joseph Rykwert. The Seduction of Place. The History and Future of the City. Oxford: England. Oxford University Press. 2000. p. 132
} 
predictable situations." ${ }^{19}$ It is the fragmentation of the city into parts, points and predefined identities, all balanced to accommodate the individual. It is a perfectly organized, perfectly striated, and clearly driven by motorization. Mimi Sheller and John Urry's essay, "The City and the Car" further describe this conflict.

The focus on urbanization as a mode of location, of dwelling, of architecture and of association has deflected attention from the ways in which movement also constitutes cities as civil spheres. If urbanization leads to the intensification of human habits, the concentration of places in space, and the unification of condensed temporal flows, then the automobilization, by contrast leads to the extension of human habits, the dispersal of places across space, the opportunities to escape certain locales and to form new socialities, and the fragmentation of temporal flows, especially through suburbanization. ${ }^{20}$
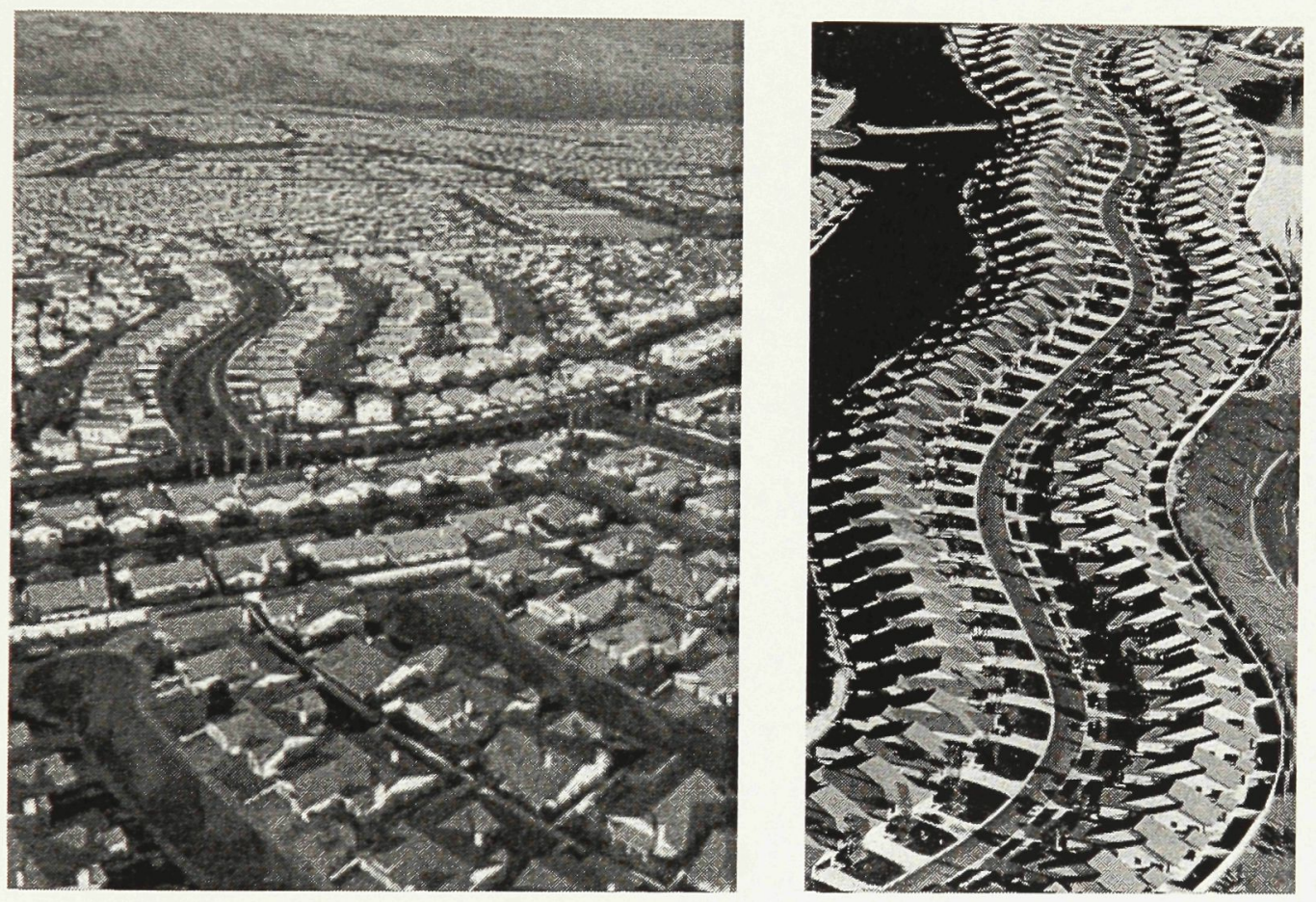

Figure 1.10 \& 1.11: Suburban Developments.

(Source: National Geographic. Digital Archive. $<$ http://www.ngtlibrary.com/ $>$ )

The contemporary city reflects this condition of suburbanization with its vast

parking lots, corporate plazas, malls, supermarkets, subdivisions and urban expressways

19 Lars Lerup. “American Speed, American Distance." New Urbanism: Michigan Debates on Urbanism: Volume II. ed. Robert Fishman. New York, NY.: Distributed Arts Press. 2005. p. 42

20 Mimi Sheller, John Urry "The City and The Car." International Journal of Urban and Regional Research, 24, 2000. 737-45. p.742 
connecting one place to another. These are the new spatial types of cities, and is the condition that needs review. How can the rigid structures of the urban condition be broken up to re-evaluate the relationship between architecture and the marking of place? In the next section on this paper, this will be explored by investigating the temporal boundaries of the city and their effects in how architecture structures the identity of place.

\section{Fields of Play}

Boundaries until now have been static, rigid and in some cases, dull. This needs to be reviewed in order to explore the conditions of temporal boundaries. Thus far, I have only briefly discussed the issue social spatiality and their effects on territorialization. This next section will reinvestigate the notion of "place," and how the event can inform us in how space is territorialized.

Sanford Kwinter invites two pathways to look at where the event can be an active element in shaping this language. The first pathway entails a revision of the concept of the object, where architecture is embedded within the institutional machine. The second attempts to conceive movement as the first principle, where time is relayed as something real in hopes to develop a theory of the "event." In the sections above, we have concluded that this first pathway leads to a two-dimensional reality. What is particular about the second path however, is the understanding of society and other cultural realms as being dynamic fields of play, where time is not static as an object within a fixed field, but instead the reorientation of geometries and patterns remain in a dynamic realm appearing over time. This is a social spatiality built from the events that take place within and around the physical territories of the city. It is a temporal boundary condition that 
manifests the milieu, where the rhythms and patterns of our movements create cycles of time and space-time relations. Temporal boundaries are potentially present everywhere. They are boundaries that have no inside or outside, they are set and specified in the act of passage. ${ }^{21}$ In a short essay by Macgregor Wise, he explains this with an example of a car passing through a street.

The bass-heavy rhythm pounding from a car driving by shapes the space of the street, changes the character of that space. Heads turn (towards, away), feelings (repulsion, identification, recognition) arise. The resonant space thus created is a milieu. Milieus cross, 'pass into one another; they are essentially communicating rhythms blends and clash. The car and its occupants cross from one milieu to the next as they venture down the street; a figure on the sidewalk is enveloped in the bubble of sound, by the street,by the milieu, and is then released again as the car turns the corner down by the light. The street had its milieus before the car arrived (quiet suburban, congested downtown) which are altered by the arrival of the car and its rhythm, but reassert themselves after it leaves. ${ }^{22}$

This rhythm is the dimension of the milieu; it is the block of space-time that captures the vibration and resonance of movement in a field. All around us, everyone, and everything, we are marking and shaping the space that we encounter. Thus, as practiced, our everydayness is flooded by constant emergences of milieus. Each milieu opens up to others, exposing a social spatiality as well as revealing the spatiality of the formal environment. This duality is the structuring of the temporal boundary conditions that I refer to as fields of play. In other words, the markings that shape and manipulate space are interconnected in creating a field. This field of play is a boundary structured by multidimensional space, always open to other elements, always changing and pre-existing the formal boundaries of the city. The field of play is a space of movement,interaction

21 Brian Massumi. The Politics of Everyday Fear. Minneapolis, MN: University of Minnesota Press, 1993. p. $26-27$ 
and struggle trying to stabilize them all. It is the beginning of the articulation between the space of sense and the space of society. Bernard Tschumi explains that "bodies not only move in but generate spaces produced by and through their movement."23 Movement is a rhythmic event that exposes new processes of the environment it passes through. It is a form of communication between the formal dimension of place and its temporal spatialities. This communication leads to the territorialization of space. Territoriality is an act and evolutionary process capturing the resonance of the formal and the temporal boundary conditions. It is the act of continuous ratification, adjusting, and transforming from one state to another. "Place" therefore, in this sense is formed by territorialization, but is a balance between the states of change. This balance however, is never concrete, therefore allowing the identity of place to continuously be redefined. ${ }^{24}$

The conception of "place" and territoriality exists in all scales of the city, from the identity of a bus stop, to the organization of a city. It is a what allows continual transformation and difference to arise. At the scale of a point within the city, this is exemplified by the urban spaces of mass transit such as the metro and bus station. Designed and constructed to move people as efficiently as possible, these spaces are filled with escalators, moving walkways, passageways and tunnels mobilizing citizens and visitors around the city. When empty, a station can be disorienting with all its passages and tunnels but once a train has arrived and its passengers enter and exit, the station comes alive in the sense that the disorienting space becomes readable. In this sense, it is only the movement within the station that orientates the traveler. The very act

\footnotetext{
23 Bernard Tschumi. Architecture and Disjunction. Cambridge, Ma., MIT Press. 1994. p. 95 Gilles Deleuze. Difference and Repetition. New York, NY: Columbia University Press., 1993. p. 
of movement is an inevitable intrusion of bodies into the controlled order of Nature, and moving through (arrival and departure) a given point violates a balance of a precisely ordered geometry. In other words, bodies can carve unexpected space through their fluid and erratic motions. ${ }^{25}$ The mass transit stations that are becoming a part of all city types is a modern urban space where the practices of the events territorialize the space, exposing the architecture but at the same time allowing the architecture to inform the participant. The experience of the metro system is like no other. It is a city of its own with no periphery. Individuals are connecting, passing and transporting themselves through the infinite number of points above. As a result, movement from one node to another becomes as crucial as the core itself. The metro system is a unique urban system; it does not modernize, it only evolves; if it is too small, it grows infinitely; it is an urban space that exists as a node in the structure of the city, but its identity is continually evolving by the events that take shape within it.

Beyond the metro station, many urban planners, designers and architects have embodied this conception of boundaries and territories. One recent example is the competition proposal for Downsview Park in Toronto by the Office of Metropolitan Architecture and Bruce Mau Design. ${ }^{26}$ It is a project demonstrating how the physical form and the social spatiality of the site are balanced through an architectural system that both affect and reflex. In November 1999, five finalists in the Downsview Park

\footnotetext{
25 Bernard Tschumi. Questions of Space: Lectures on Architecture. London: Architectural Association, 1990. p. 98

26 Another case study was conducted for this thesis project. Refer to Appendix II: Curitiba, Brazil on the affects off mass transportation on the planning of Curitiba.
} 
competition were asked to developed schematic design proposal for the redevelopment of an old military base in the heart of the greater Toronto area. ${ }^{27}$

\section{Downsview Park Competition}

The Downsview Project was a scaled project requiring the competitors to explore new relations in social spatiality and its relations to urban form and urban growth. In contrast to urban parks such as Central Park in Manhattan, Downsview is not to be developed as a fixed and static design solution (as a physical and territorial urban island) but rather it is a place that will be orchestrated over time, transforming in response to future environmental, social and economic conditions. ${ }^{28}$ The primary question the competition embodied was the review of the term "park," as it was not to be understood as a natural space for the public, but as a metaphor to system of program and material processes. The relationship between the user (citizen) and the park (a open place for interpretation and transformation) would be a territorial relationship where architecture would play a role of balancing both sides. Downsview's future, as a place to retain its strengths cannot be defined as a static bank of systems but instead as a system of production - allowing the restoration of the ground to be a creative intervention predicated in the past. A system where "nature and humanity within it are to be treated as a dynamic phenomena, constantly changing and interacting no longer to be described as a balanced site but instead ever new and ever surprising." As the competition brief states, the project demands an engine of producing a self - organizational product that enables

\footnotetext{
27 Refer to Appendix II for details about competition.

28 Charles Waldheim. "What's Up Downsview?" Canadian Architect Magazine. November 2003, 16-17. p. 16
} 
the system to exist under various conditions. The environmental and programmatic requirement will change, the context will change and the park must be able to adjust to such evolutions. ${ }^{29}$

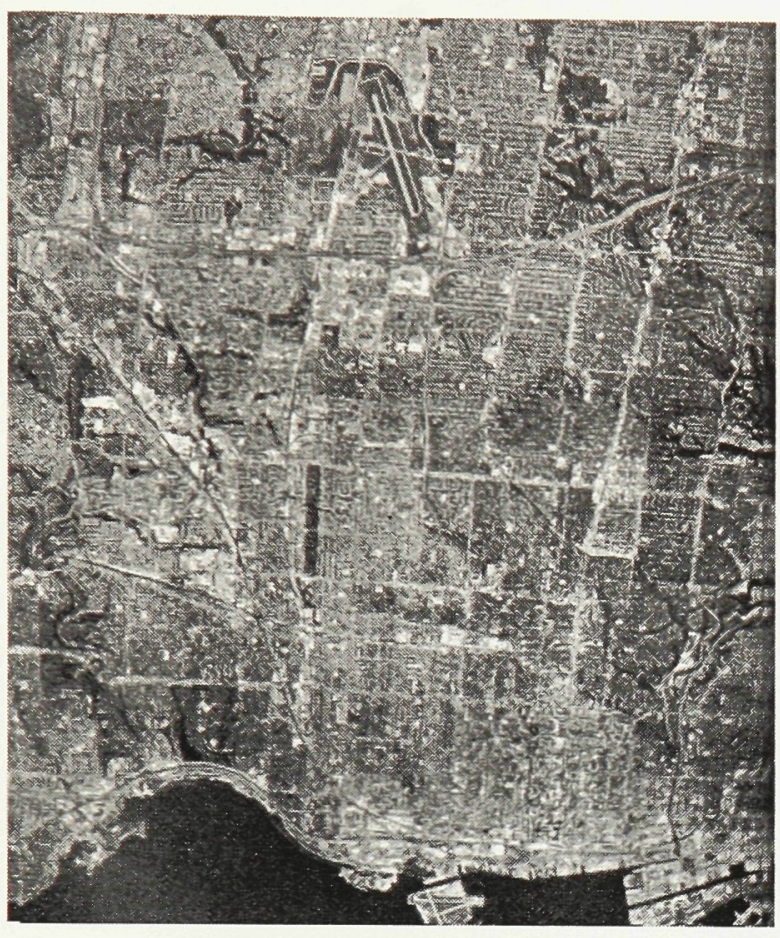

Figure 1.11: Downsview Park Competition Site Map. (Source: Czerniak, Julia. Case: Downsview $\underline{\text { Park Toronto. New York, NY: Prestel Publishing, }}$ 2001.p. 15).

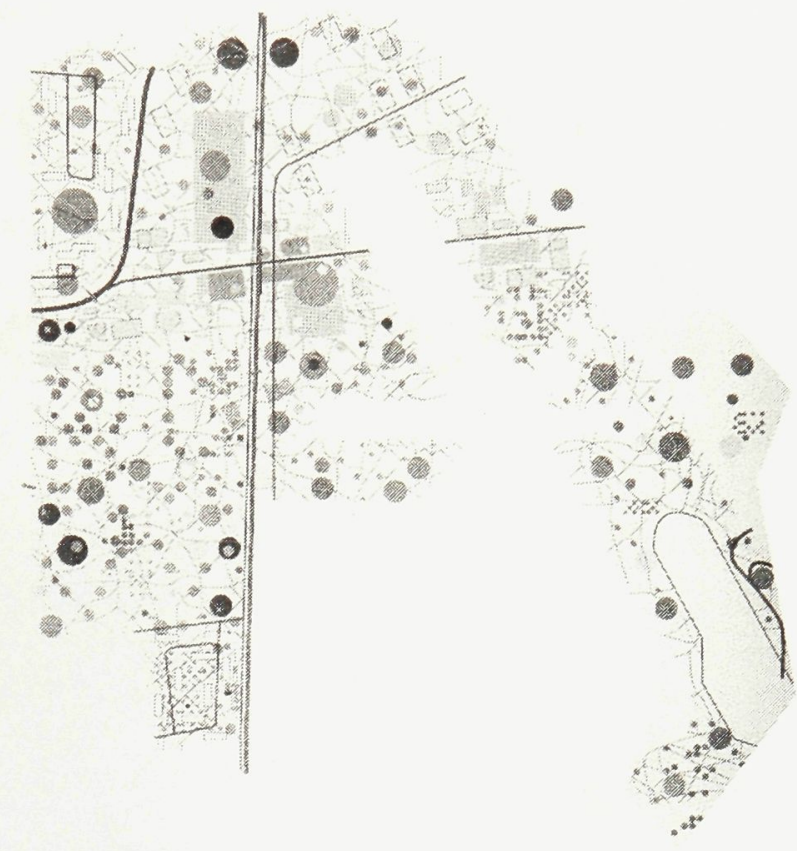

Figure 1.12: Downsview Park Competition, Winning Entry by OMA and Bruce Mau Design. (Source: Czerniak, Julia. Case: Downsview Park Toronto. New York, NY: Prestel Publishing,. 2001. p. 23)

The winning entry for the Downsview competition was entered by Office for Metropolitan Architecture (OMA) and Bruce Mau Design (BMD). The project entitled, Tree City, is a unique project where Rem Koolhaas and Bruce Mau propose the construction of Downsview as an urbanization of nature. For Koolhaas, the City today is a world without urbanism, only architecture, and ever

\footnotetext{
29 During the early 1940 's, the federal government of Canada established several military bases throughout the country, the site of Downsview Park, where at this time was located along the periphery of the city; today however, is at the core of Toronto's urban sector. In 1994, the federal government decommissioned Downsview's military base allowing this 320 -acre site to return to its origins in public ownership.
} 
more architecture, where the only way urbanism may resurrect itself is if we consider it as an endless framework - a process that has no definitive form - the manipulation and hybrid of successes and error formed in our past. ${ }^{30}$ Tree City is reflection of this condition. It is map of the network that will guide the site into future developments. The virtual map is a situational map, in the sense that the information presented is only sufficient to guide the site from stage to stage without any consideration to form. The architecture is a non-definitive element of the park, and only through time will the site find its language.

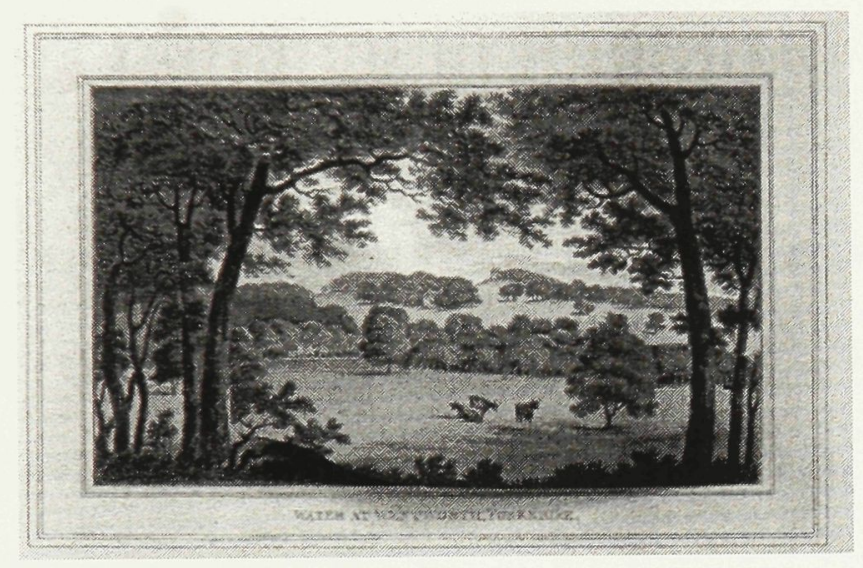

Figure 1.3: English Garden. Sir Humphrey Repton.

(Source: Smithsonian Institution Libraries. Voyages. $<\underline{\text { http: } / / \text { www.sil.si.edu/ } />\text { ) }}$

Tree City is based on a network of tree clusters where each will develop to become environmental sites leaving the spaces in-between to become cultural spaces. The creation of tree clusters as a driving force of ecological development is not a contemporary idea. Sir Humphrey Repton used perfect tree cluster typologies during the early 19 th century to generate contextual development. ${ }^{31}$

\footnotetext{
$30 \quad$ Koolhaas, Rem. "What ever happened to Urbanism.” S,M,L,XL. New York: NY: Monacelli Press, 1994.

31 Czerniak, Julia. Case: Downsview Park Toronto. New York, NY: Prestel Publishing, 2001.
} 
But in contrast to Repton's static typologies, Tree City's clusters is only a form of expression of a natural "otherness." Each tree cluster, varying in ecology and vegetation, collectively creates a mature environment with youthful areas in between. The clusters have no identity, no history and no projection in the future possibilities of its significance -they are objective markers setting up boundaries within the site, but until manipulated or encountered, they will remain dull objects. To prevent this from occurring, Tree City structures its spatiality outside the limits of the site in bleeding the park into its surrounding context. By accepting the residential landscape into the park's landscape Downsview will prevent itself from remaining a territorial island. To begin this process of integration, Koolhaas and Mau have layered a network of pathways that weave in all direction within the site, giving citizens a thousand entries and exists. In one sense, these pathways are physical in restricting one's movement throughout the park, but in another, these pathways are representational in forcing citizens to move beyond their limits to create new pathways. 

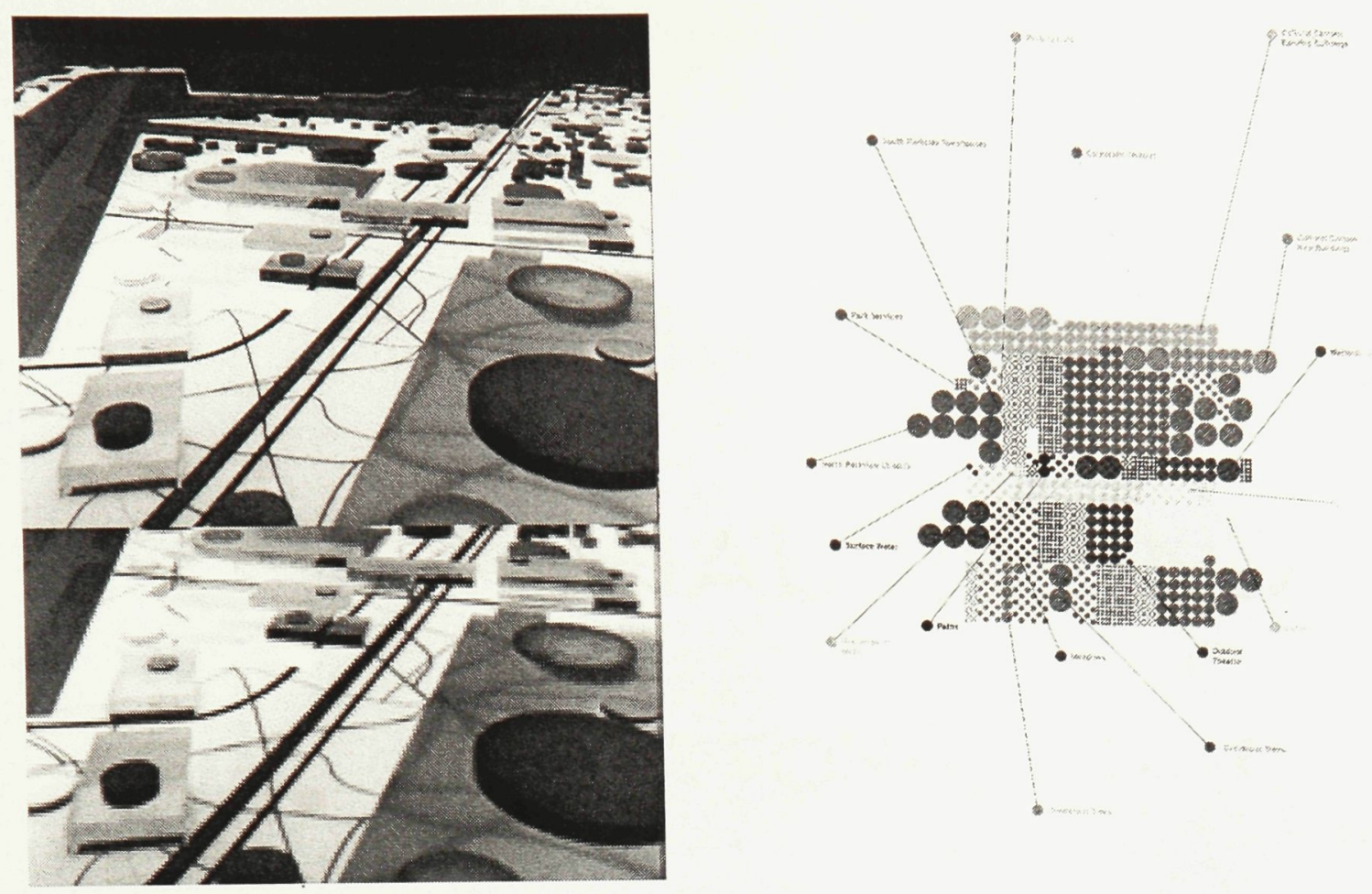

Figure 1.14 \& 1.15: Program Density Diagram. OMA \& BMD

(Source: Czerniak, Julia. Case: Downsview Park Toronto. New York, NY: Prestel Publishing,. 2001.p. 27)

The project put forth by OMA and BMD is a system that uses nature and economics as the driving force behind the success of Downsview Park. However, in contrast to all the other competitors, this project is primarily a project based on the process, allowing the situational matrix to be broken and more importantly, leaving the final outcome unknown. Tree City attempts "to do more by building less, producing density with natural permeability, property development with perennial enrichment." 32 The design presented is simply a possibility, not a literal projection of the site. Instead, the design lies in the writings. The annotated process of the project manifests the project into reality. The actual matrix cannot be defined, nor can the placement of any of the programmatic requirements. The

$32 \quad$ Ibid. p. 74 
matic presentation of one possible scheme that can be

les.

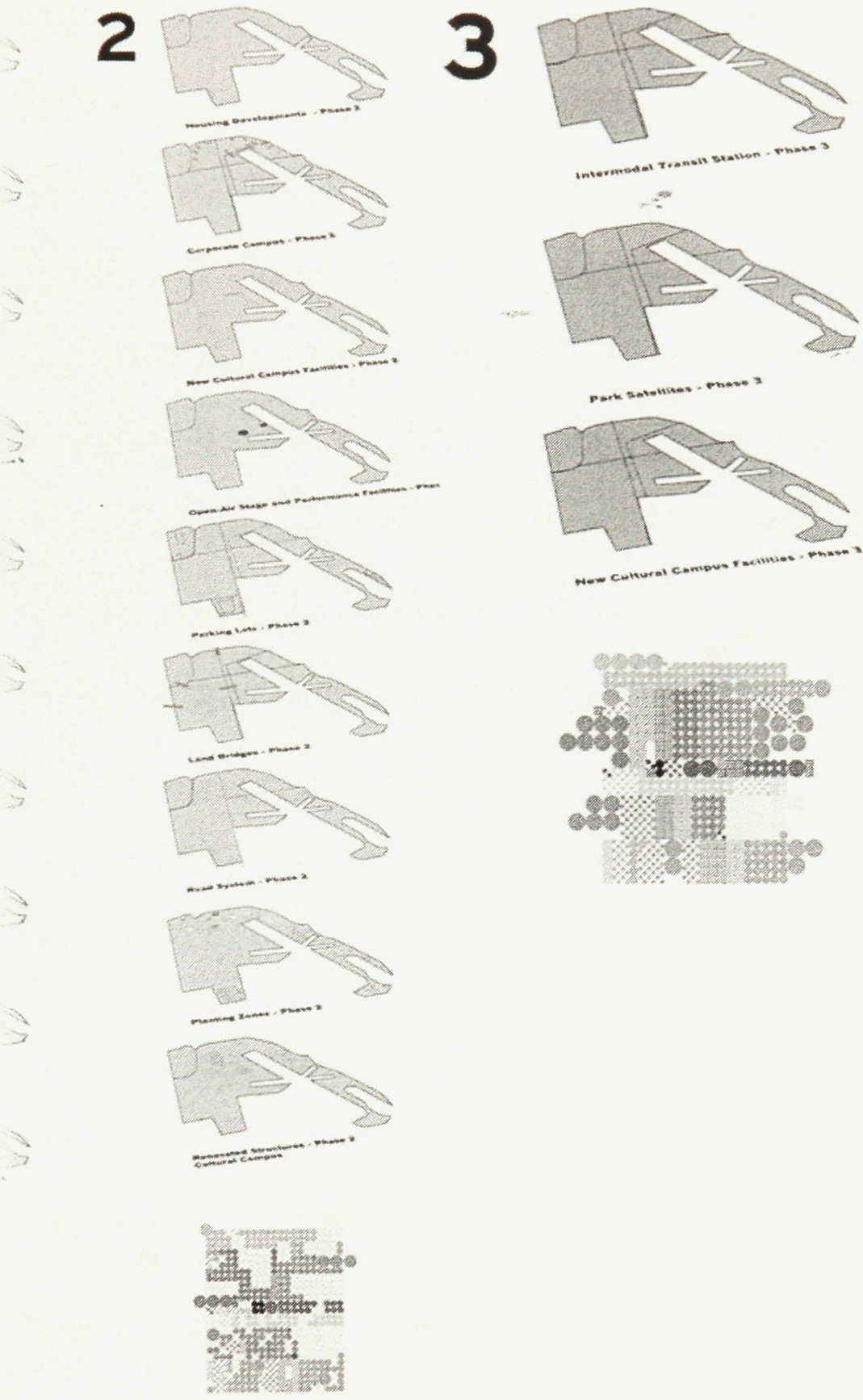

Irowth Pattern. OMA \& BMD(Source: Czerniak, Julia. Case: York, NY: Prestel Publishing,. 2001. p. 28). 


\section{Conclusion}

John Rajchman states that today, we are faced with two problems: how to get away from the utopian images and how to develop a new conception of the city. ${ }^{33}$ This paper, thus far has investigated a way of reviewing the formal (utopian) city that emerged from the twentieth city modernist, by exploring the role of architecture in the formal and temporal boundaries of the city. The contemporary city no longer conforms to an archeological model of accumulating layers of history on top of each other. Instead, it seems urban sprawl has resulted in cities being accumulated horizontally, where the private automobile connects us from one place to another. To break this conception, this paper suggests that "place" should be understood as a state of change in the territorialization of space. Architecture is no longer a free standing object, but is a virtual object where only when it is practiced, the architecture of the space is exposed. Architecture informs us with its formal geometries, but the identity of place is revealed only by the manifestation of the milieu.

The application of this conception however, is not as readably visual as the modernist images of the city. Mass transit, in particular the metro system, has a spatiality where the architecture of the space is only exposed by the rhythmic patterns of moving bodies. It is a type if urban space that on one level is the formal marking of a place, but on another, its identity is constructed over time by the events that pass through it. At a larger scale, Rem Koolhaas and Bruce Mau have demonstrated how the planning of an urban "park" can be constructed as a guide that allows the identity of the place to emerge 
over time. The proposal is a situational map, in the sense that it represents possibilities, not the outcome.

Cities have a formal geography - building, streets, highways and parks - all interconnected allowing us to move from one node, place, and neighborhood to another. Cities have a social geography - public events, private events, car culture, and street culture - the elements inhabiting the physical. Together these two spatialities create a critical thought process that removes architecture from its rigid properties, and into a dimension of the city that generates unexpected occurrences eventually guiding the city through its continual transformation. Therefore the new technologies and forms of communication that we, as a society utilize in our everydayness is creating all types of places, and if architecture is left as formal representation, we are rejecting the very act of this change. 


\section{Llanos del Solar, Chile \\ Design Proposal}

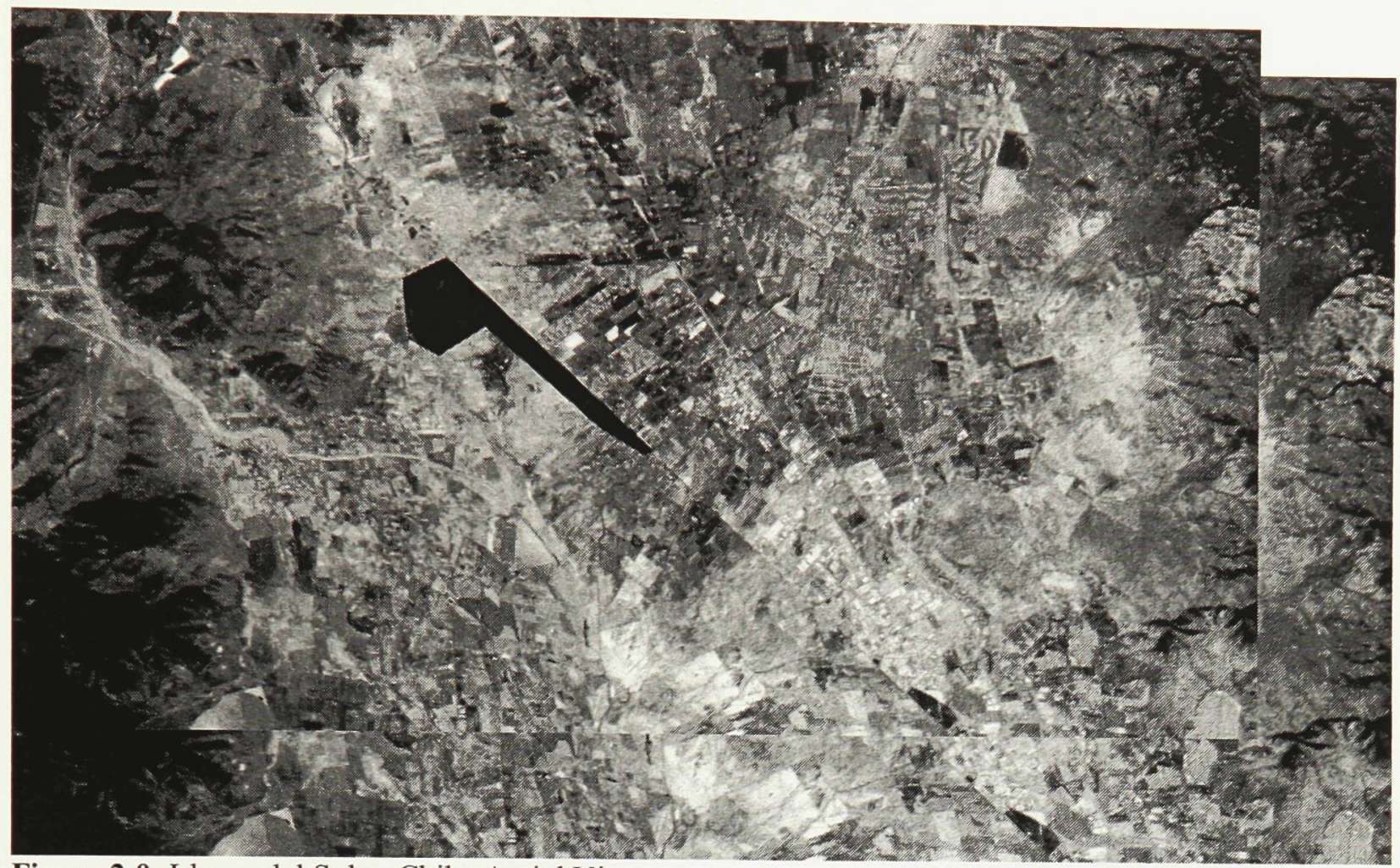

Figure 2.0: Llanos del Solar, Chile. Aerial View.

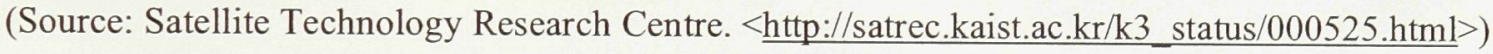

Over the next twenty years, Gran Santiago is to double in surface area. With a

population of over six million inhabitants, Gran Santiago's current growth is following a

typical path of decentralization. Great suburbs outside the city limits are attracting

citizens into suburban communities that work for the individual family (the private

property or group) rather than the collective. This is best exemplified in the current

developments such as Curauma, Lo Aguirre, and Piedra Roja. ${ }^{34}$

The site for this project, located 25 kilometres from Gran Santiago is in the

Chacabuco region. Currently three cities north of the site, Lampa, Batuco and Colina, are connected along a east - west axis, with Estacion Colina located at the site's southern tip.

34 For more information: Curauma: http://www.curauma.cl; Lo Aguirre: http://www.loaguirre.cl; Pierda Roja: http://www.piedraroja.cl. 
With a population of 150,000 citizens (Colina holding the majority with 90,000), this region is predicted to grow to over 650,000 by 2025 . Between these cities, the rural land is filled with industrial and ecological farms and s sparse housing in their support. The road infrastructure is structured by highway 5 (stretching from the south of Chile to Peru) run between Colina and Batuco, however, in order to travel to any city, one must travel along side roads and local highways. An abandoned rail-line also stretches through the region connecting Santiago to Peru and Bolivia, runs along the eastern boundary line of Llanos del Solar. ${ }^{35}$ This rail-line is the only direct connection between the proposed site and the city of Santiago. It will become one of the most important factor in the strengths in the growth of the Chacabuco region.

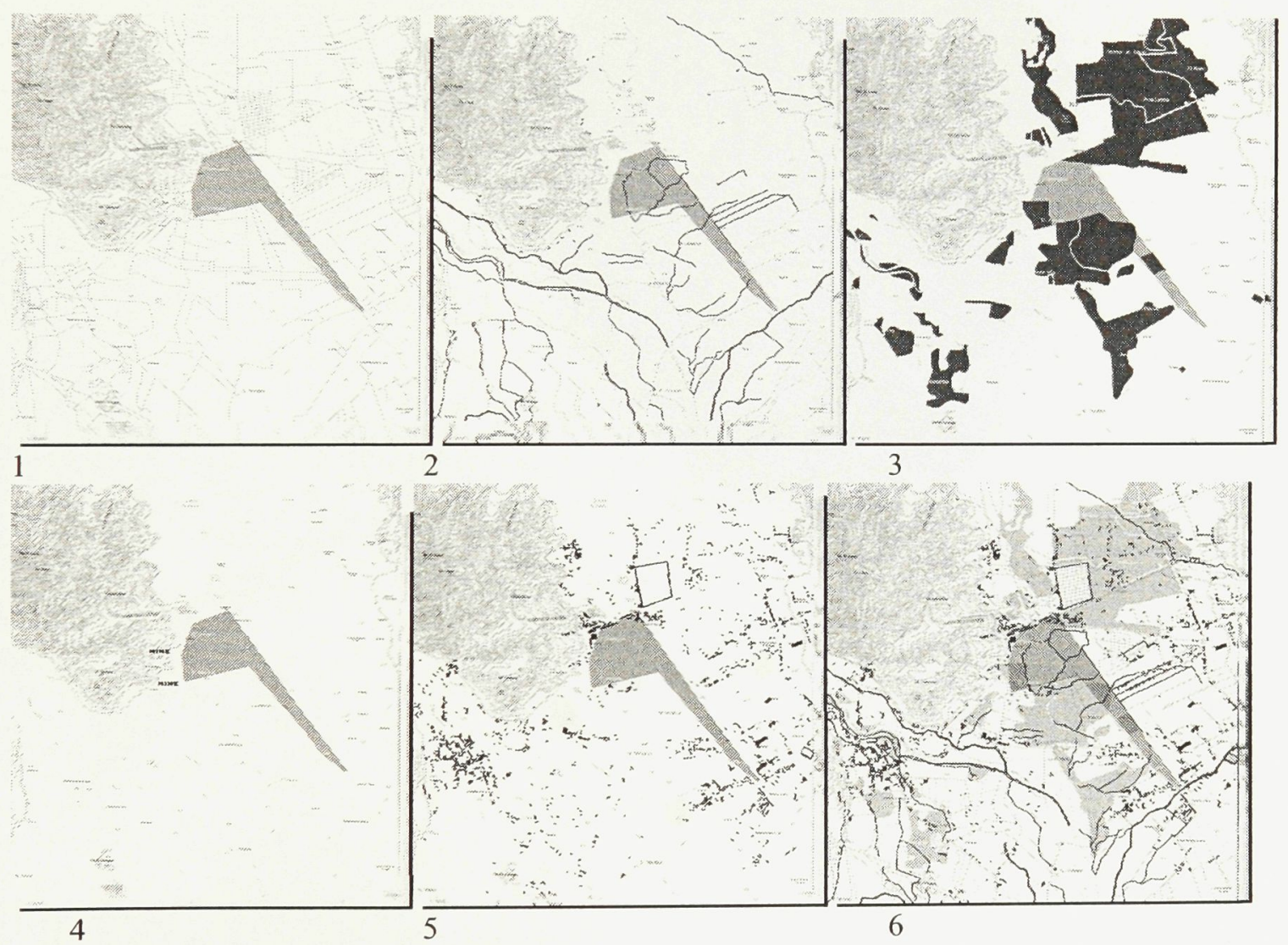

Figure 2.1: Chacabuco Region.

1. Road Infrastructure; 2. Rivers; 3. Farm Land; 4. Mines; 5. Housing Density; 6. All Layers (1-5).

35 The northern rail-line stretching through the Chacabuco region has been abandoned since the mid1980 's, but is currently been redeveloped is assumed to be in full function by 2015 . 


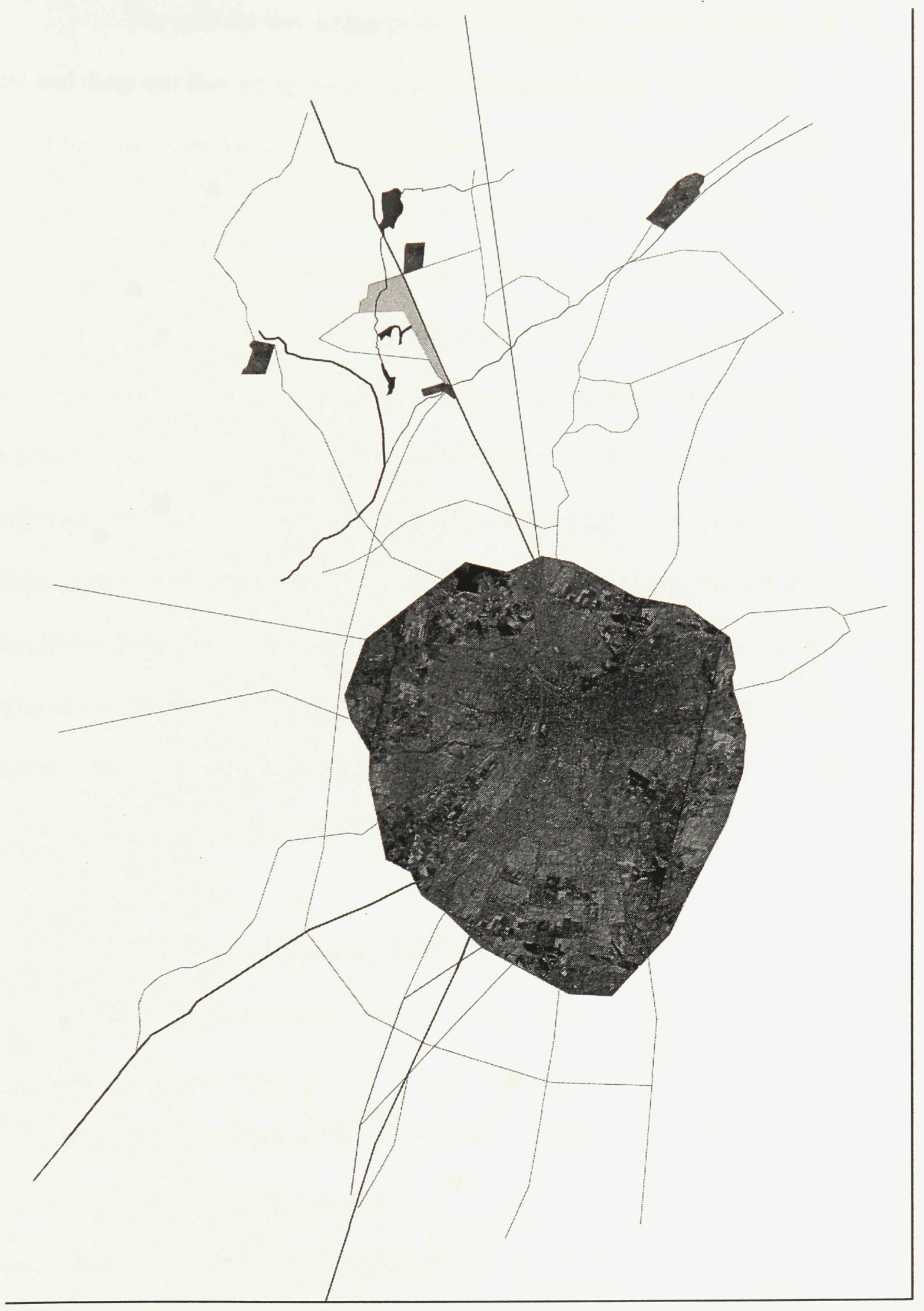

Figure 2.2: Infrastructure for Gran Santiago. Site for Llanos del Solar in grey. 
The goal for this design proposal is to create a series of tools (both in text and diagram) that set-up conditions, situation, and events. The overall proposal for Llanos del Solar is to create an architectural landscape that embodies the conception of fields of play outlined in the sections above. The emphasis of the design proposal therefore, is on the growth of the city - not the formal geometry of the city. As an architectural design proposal for the city of Llanos del Solar, the design explores the idea of building envelopes and how they can be structured to allow for overlaying landscapes, leading to a city fabric composed of old and new spatialities. Traditionally, we understand building envelopes as $\min /$ max points, for example the lowest one can build is 3 metres below grade, 20 metres above grade, have a setback of 1 metre and must leave $5 \%$ of grade level as open space. Building envelopes are a type of virtual landscape guiding the way architects respond to their surroundings. It is boundary system that sets limits and restrictions to the formal dimension of a city. However, it is also a field that allows for interpretation.

As an architectural exploration, this design proposal is meant to investigate the potentials of building envelopes and the effects on how spaces can be structured. To do so, I have added one more layer onto the common building envelope limits. This is a medial limit that I shall call a Wrap. A Wrap is fragmented building envelope that passes on top, underneath and in between an existing urban fabric. When a new building needs to be built, it will need to respond to this new building envelope (on top of all the over restrictions), however the architects can interpret the wrap into many different ways. In the 
following pages, a series of text and diagrams will aid in the description of this design proposal 


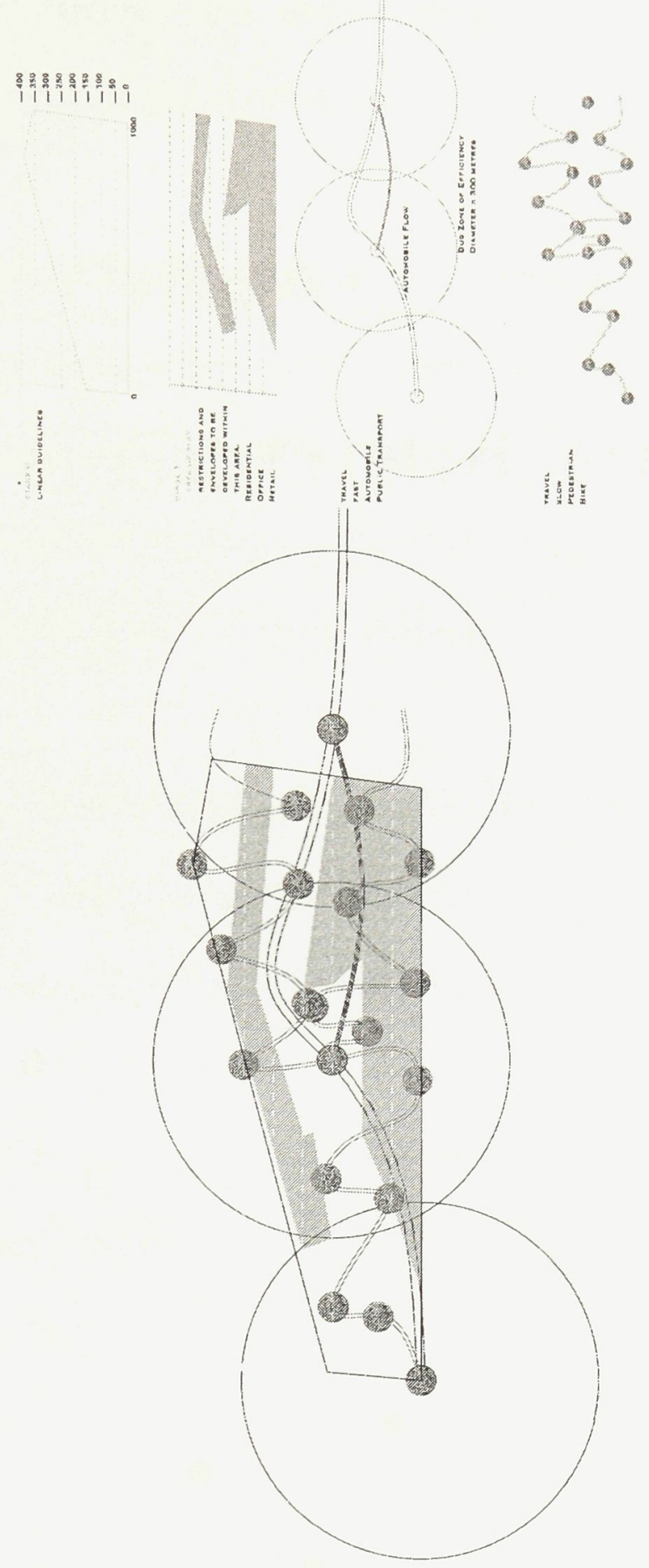

Figure 2.3: Concept Diagram

In figure 2.18, the diagram is structured in four parts, (i) being the actual site boundary of the site; (ii) the area to be developed (grey) along the growth corridor (white); (iii) The bus route; (iv) layer of pedestrian movement crisscrossing in all directions of the site. 
To create this dynamic and ever-interpretive architectural landscape, the guidelines and rules in this proposal are broken down into three phases.

\section{Growth Map}

1. The first is to create a initial growth pattern for the city - a foundational structure that will prevent the city from uncontrollable growth. This growth pattern is a map for placing of zoning densities both within and outside the city boundary limits. This internal and external map will allow adjacent cities in the future to "attach" to the infrastructure of Llanos del Solar.

\section{Initial City Fabric}

2. The second phase is the creation of a foundational city fabric. The existing site is vacant, with very little existing context to react to. ${ }^{37}$ The goal for this initial stage is to create an environment that will generate a response in the following steps.

Wrap

3. As a response to the initial fabric, the third phase of this deign proposal is a set of building envelope guidelines that will act as generators for deriving future developments in the city.

36 The infrastructure of the city is to create a permeable city boundary so adjacent cities can connect to the structure of Llanos del Solar. This is to create smooth transitions between connecting cities.

37 Batuco sits just north of the site, while Estacion is at the southern tip, but over $90 \%$ of the site's context is rural land. 


\section{Growth Pattern}

The goal for the growth pattern is to develop a structure that will guide the city's maturity by preventing the city from standing as a island within the Chacabuco region, but instead as an element in network of communities and cities.

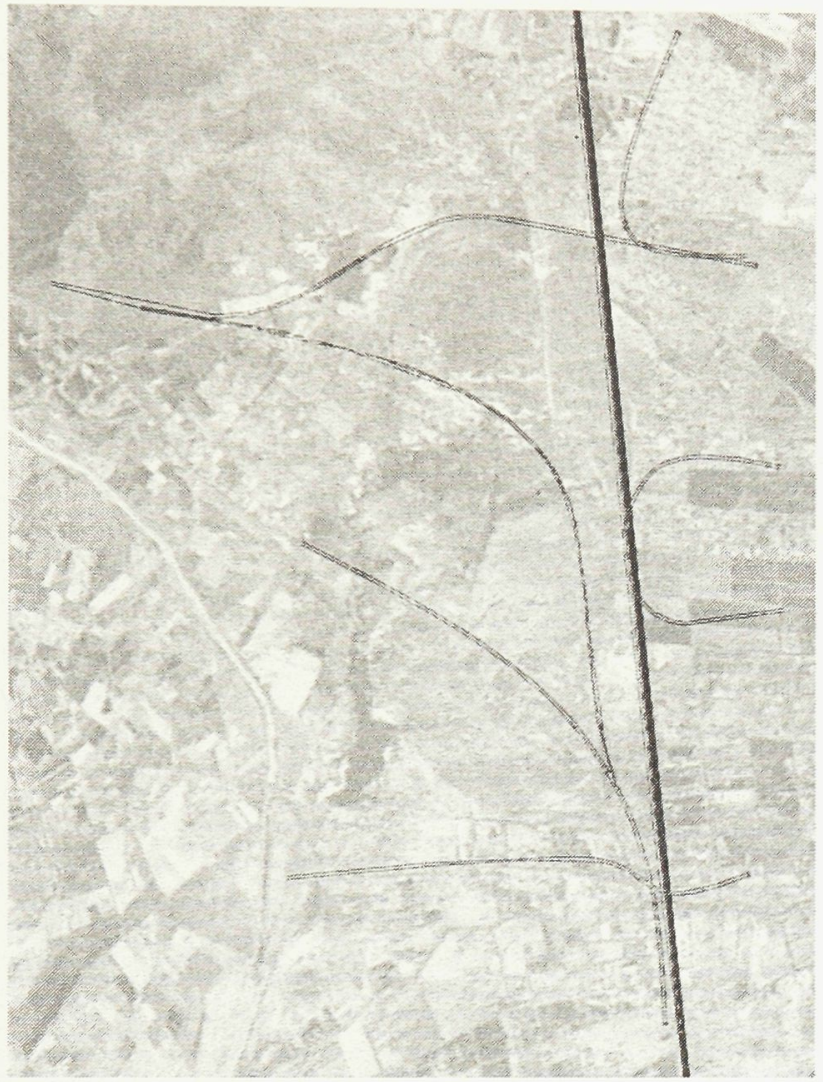

Figure 2.4: Existing Flow of Movement.

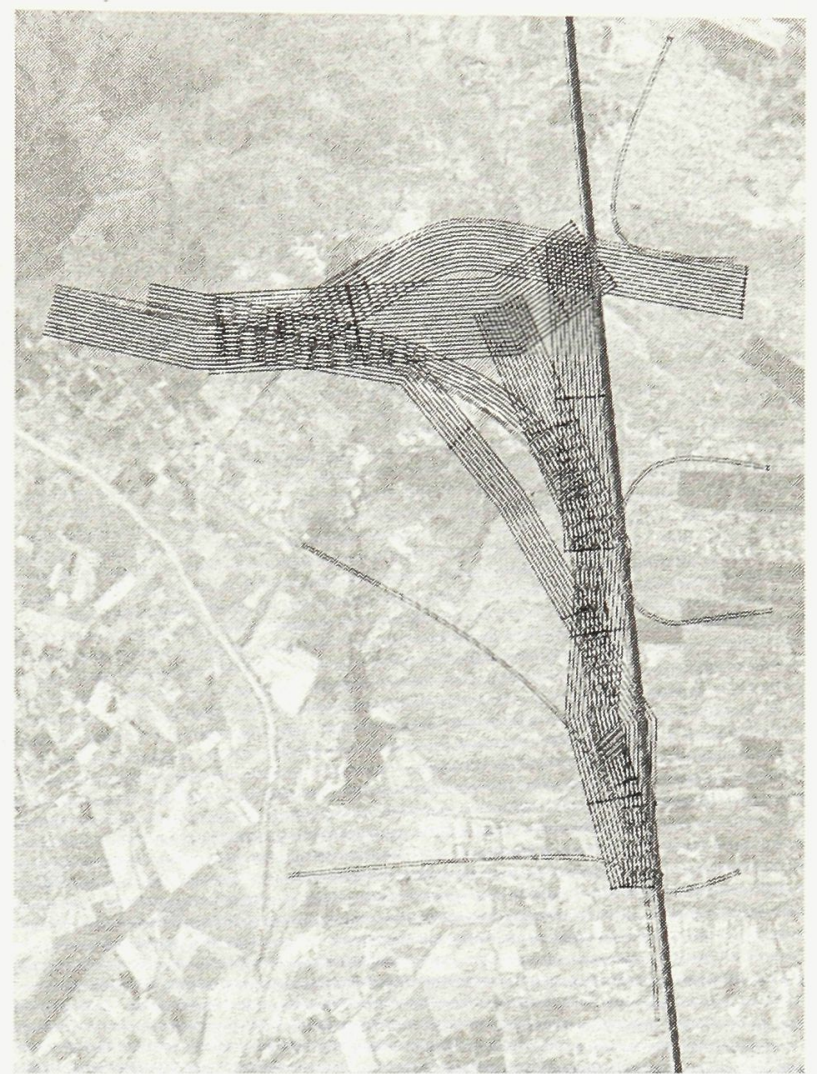

Figure 2.5: New Growth Corridors.

The existing movement (see figure 2.11) around the site works along two primary axes (north - south and east - west). Lampa, Batuco and Colina are all connect by a roadway running along the east-west axis, while a single unpaved roadway along the north-south axis connects Batuco and Colina. If these objective boundary lines remain the primary form of movement, the interaction and crossings between one city and the next will not allow for cities to join efficiently. To prevent this, the growth pattern for Llanos del Solar has been derived as series of crossing linear growth lines bleeding into adjacent 
environments to break the existing structure. See figure 2.12 and 2.13. Though the new growth map does not literally display the flow of movement, the bleeding lines will allow the city of Llanos del Solar and its adjacent cities to share a common boundary characteristics. 


$$
T
$$




\section{Initial City Fabric}

This base is not a pure representation of the actual building geometries, but a map of building densities and their zoning programs. It is a "starting" environment for citizens to inhabit.

Low-Density:

Lot sizes are to range between 60 to 100 square metres. In figure 2.15 , three lot sizes were assumed in the creation of the density map. Lot-size A at $60 \mathrm{~m}^{2}$, Lot-size $\mathrm{B}$ at $75 \mathrm{~m}^{2}$, and Lot-size $\mathrm{C}$ at $100 \mathrm{~m}^{2}$. In the first three maps, a single lotsize was multiplied along a $1000 \times 500 \mathrm{~m}^{2}$ area, and the fourth displaying the possibilities when lot sizes are mixed. Refer to figure 2.15.

High-Density:

In a $50 \times 100 \mathrm{~m}^{2}$ lot, three different building patterns were sketched out, and repeated in 9 different ways into a $1.5 \times 1 \mathrm{~km}^{2}$ area. Though some patterns allow for a higher density than others, patterns 7,8 , and 9 allow for the most dynamic. Refer to figure 2.16 . 

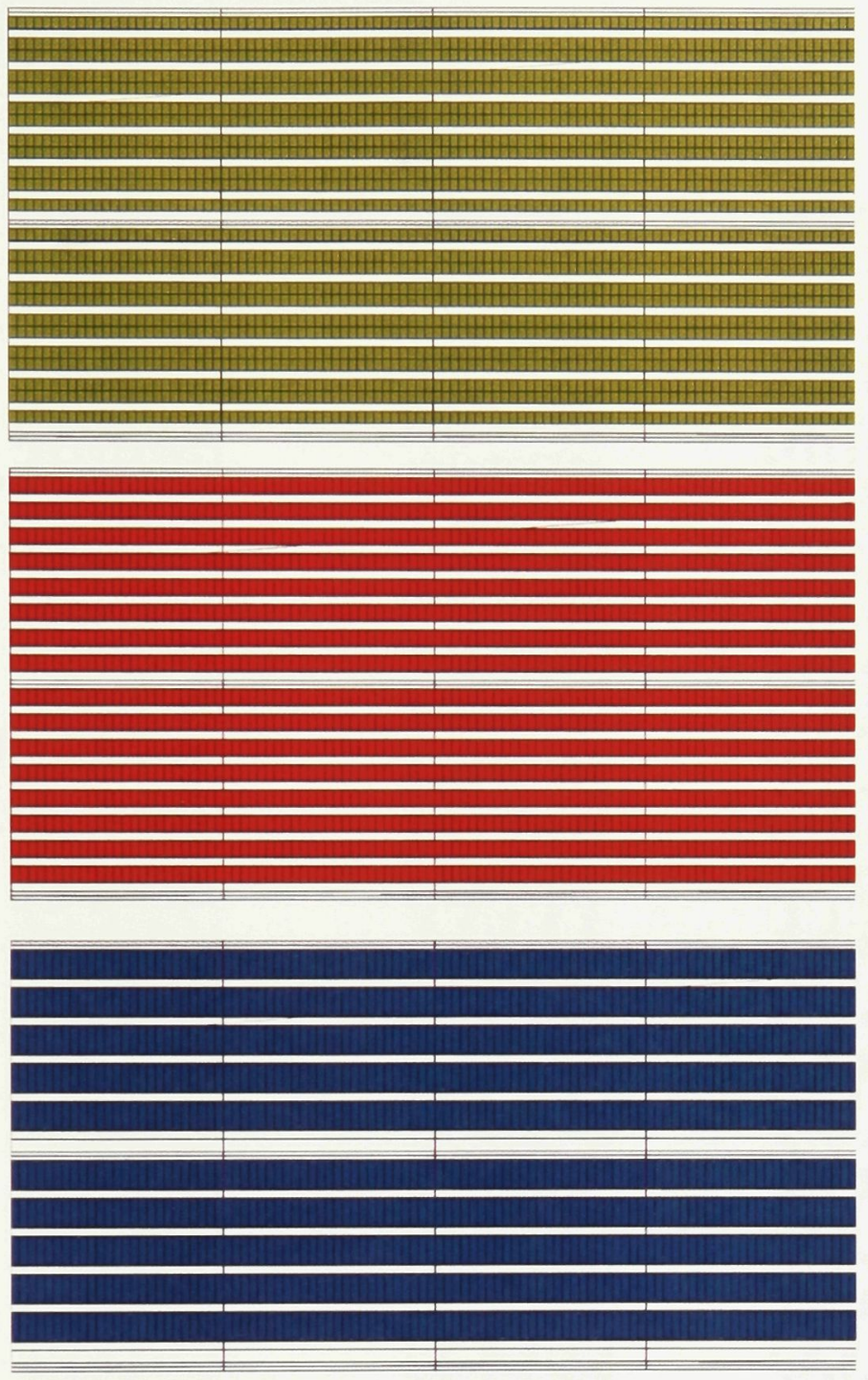

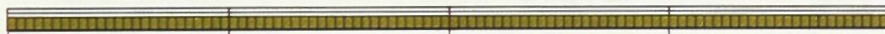

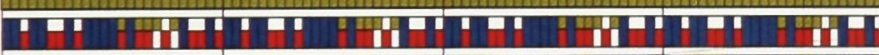

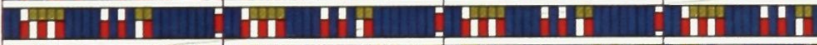

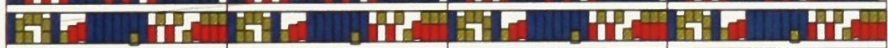

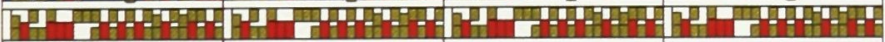

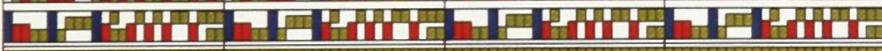

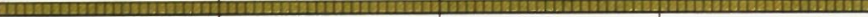

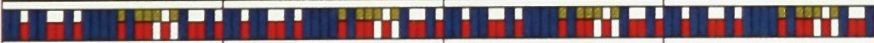

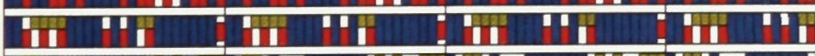

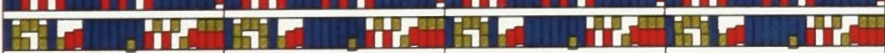

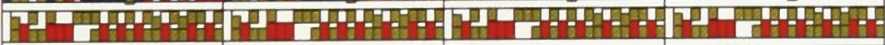

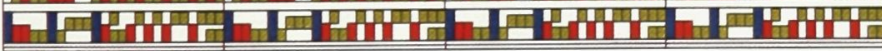

Figure 2.8: Residential Pattern.

Yellow: Small Lot Size: $60 \mathrm{~m}^{2}$

Red: Mid Lot Size: $75 \mathrm{~m}^{2}$

Blue: Large Lot-size: $100 \mathrm{~m}^{2}$ 


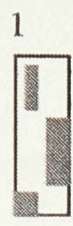

1 REPEATED

111111111111

II III

Milini

I I I III

HIIIIIII

IIIIIIII

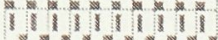

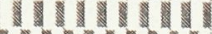

minimi

IIIIIIII

iviliti

IIIIIIIIII

11/1/1

IIIIIIIIII

$11 \mathrm{HI} / 1$

1111111

जilini

IIIIIIIIIIIIIIIIIII)

Minini

1.1111111

1+2 REPEATED

a d I I

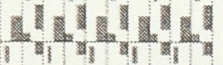

- .

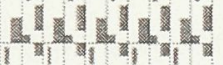

- . I I I I I

1.

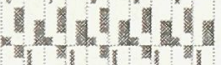

2. 1. 1.

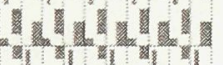

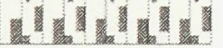

1+2+3 REPEATED

1. I.

1.

1. 1,1

1. तो

1. D.

y.

(1) $\left.{ }^{2}\right)^{2}$

1. 10.25

n.

1)

(1)

n.

1) IIJI
2

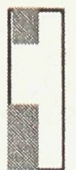

2 REPFATED

НIIHIIIIH

IIHIHIIIII

HIIIIIIII

HАIIIHIII

HНHIIIHI

HกIHกิบ

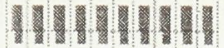

Hับแกนกแ

Нันกันศน

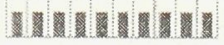

1+3 REPEATED

IIIIII

in $=11$

Fin

"in

$1=1=1$

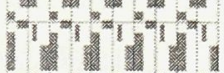

$\lim =1 / n$

mind

$1=1)^{2}=$

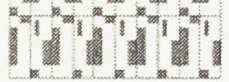

1+2+3 FLIP' ROTATED

IIIII

1) $v^{2}$ in

1. in

1in in in

a d I

i.

$1+1=$

- in

1101

ininili
3

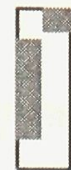

3 REPEATED

milniาin

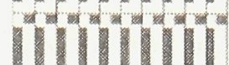

ตับัทดทัตั

ตัทับทัตั

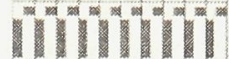

iiiniī

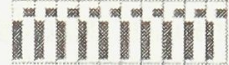

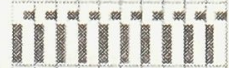

แับทด่าที่

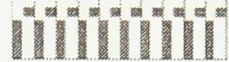

2+3 REPEATED

(1)

IIII.

1. . . I

1)

1. 1.5 .

1) 15,15

1. 12,1

1.

1.

- 10

$1+2+3$ FLIP: ROTATED

1.

IIIII)

1. ini

11.1. 11

1) 10

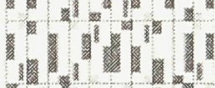

1.1.1.1.

in

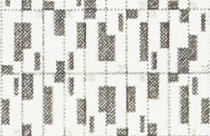

Figure 2.9: High Density Patterns. 


\section{Wraps}

The overall concept for the Wrap is to create a response to the initial fabric by creating a series of building envelope guideline that will architects and developers to create new layers into the city's cycle of maturation. Traditionally, we understand building envelopes as $\min /$ max points, for example the lowest one can build is 3 metres below grade, 20 metres above grade, have a setback of 1 metre and must leave $5 \%$ of grade level as open space. This general list is common, and this masterplan follows the same foundation, except adding one more point to this list. This is a medial building envelope which I have called Wraps.

Expressing this virtual landscape, the Wraps are expressed in $\mathrm{x}, \mathrm{y}$, and axes to form a fluid landscape. The Wraps are non-definable in the sense that they are firstly only explained in text with supporting diagrams, but they are to be interpreted and defined in the formal reality by the planners and architects.

\section{Dense Neighborhoods}

Building Envelopes + Wraps

Goal: Interconnected network of building envelopes creating a virtual landscape that future developments are to follow.

- Min. - The lowest vertical dimension that buildings may occupy.

- Lowest point to be 3 metres below grade.

- Ground Plane - The existing grade level.

- Wrap - The medial (Refer to the table below for more information)

- Building envelopes to be defined by city officials 
- Developers and architects are to use the rules to determine which programs they are allowed to build in their selected sites.

- Max. - The highest vertical dimension that buildings may occupy.

- Max vertical limit is to oscillate in height.

\section{Wrap}

\begin{tabular}{|l|l|l|l|}
\hline Name & Geometry & Program/ Function & Sample \\
\hline Wrap & $\begin{array}{l}\text { Non-symmetrical; Undefined } \\
\text { Landscape; may be manipulated } \\
\text { (cut, extended, shortened) when } \\
\text { further rules are applied. }\end{array}$ & $\begin{array}{lll}\text { Multifunctional; } \\
\text { Landscape; Zoning Bylaw; }\end{array}$ & $\begin{array}{l}\text { Green Space, } \\
\text { Walkway, } \\
\text { Bylaws: Set-back/ } \\
\text { Height } \\
\text { restrictions }\end{array}$ \\
\hline
\end{tabular}

- The function of the wrap is to create a continuous plane that crosses and passes on top of existing fabric. It is medial building envelope that may contain a function (that the architects will defined): walkway, seating, garden, public program, but it is not necessary. They may simply shape the formal space.

- Wraps' materials are undefined, nor the actual construction detailing. Material and detailing to be chosen by architect in their design. 


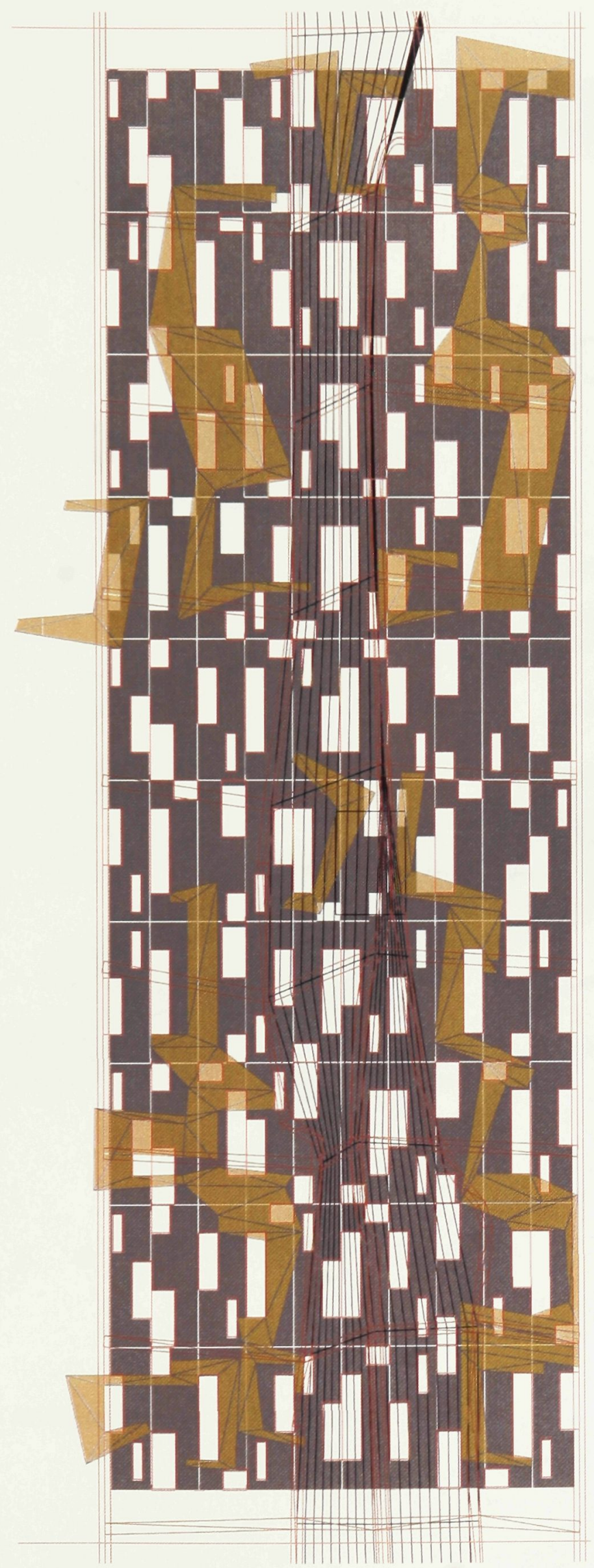

Figure 2.10: Wraps. Plan. 

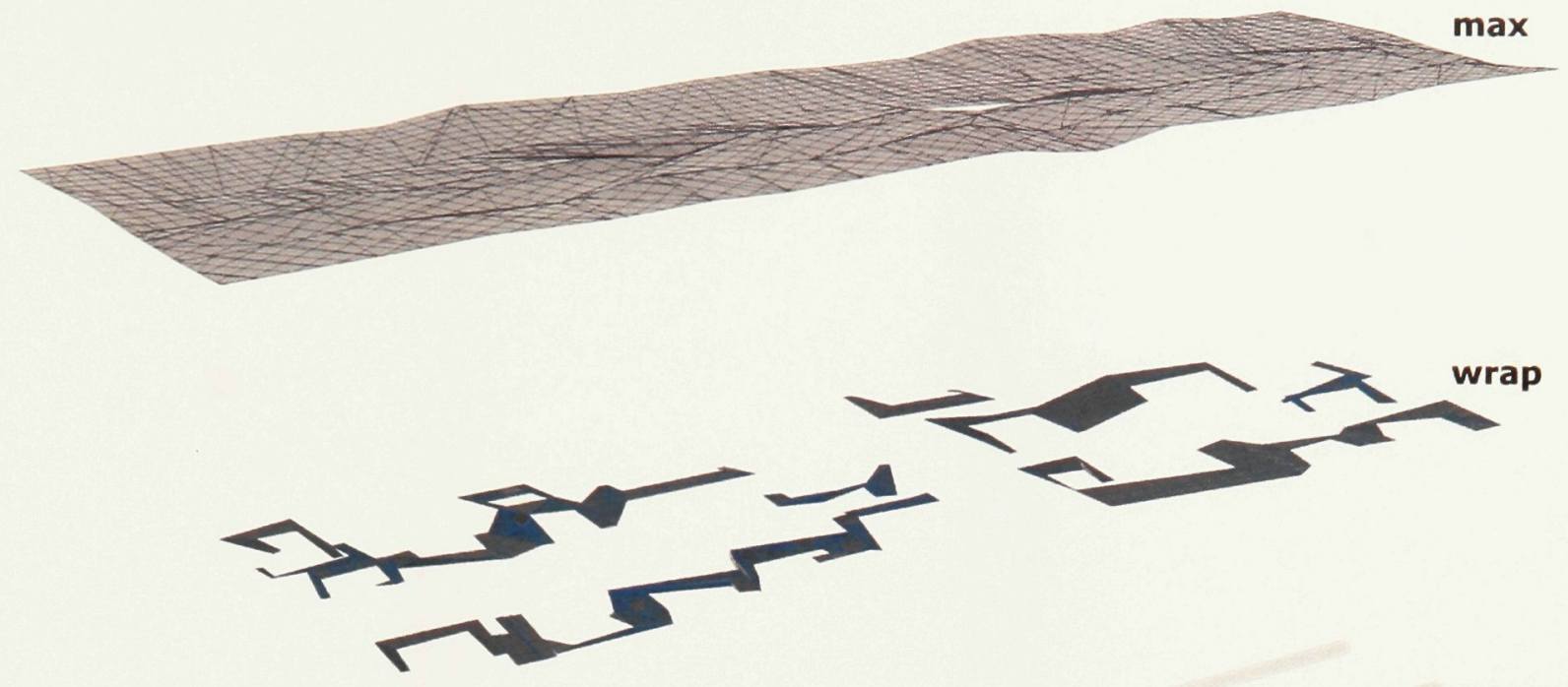

streets

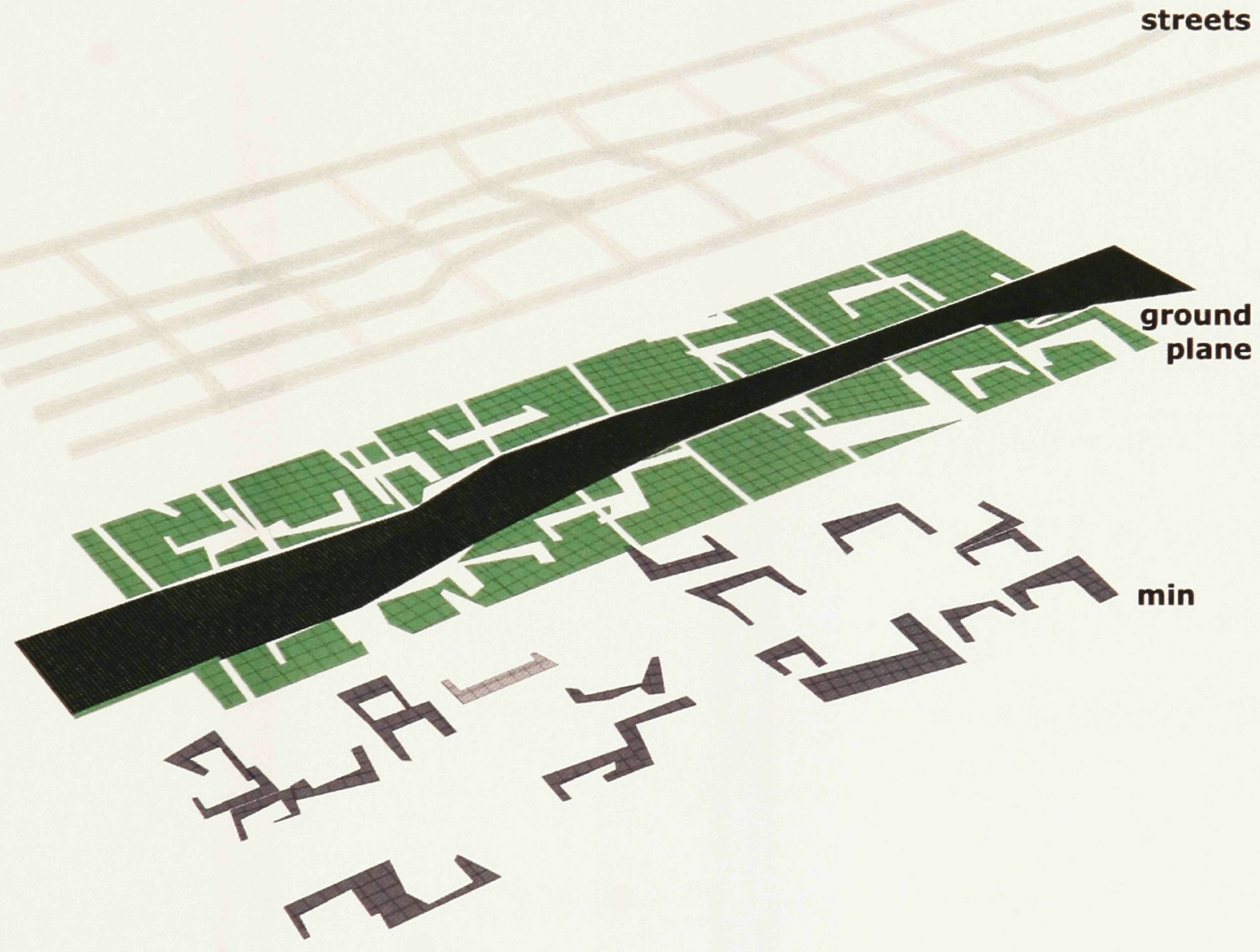

Figure 2.11: Building Envelope. Exploded View. 


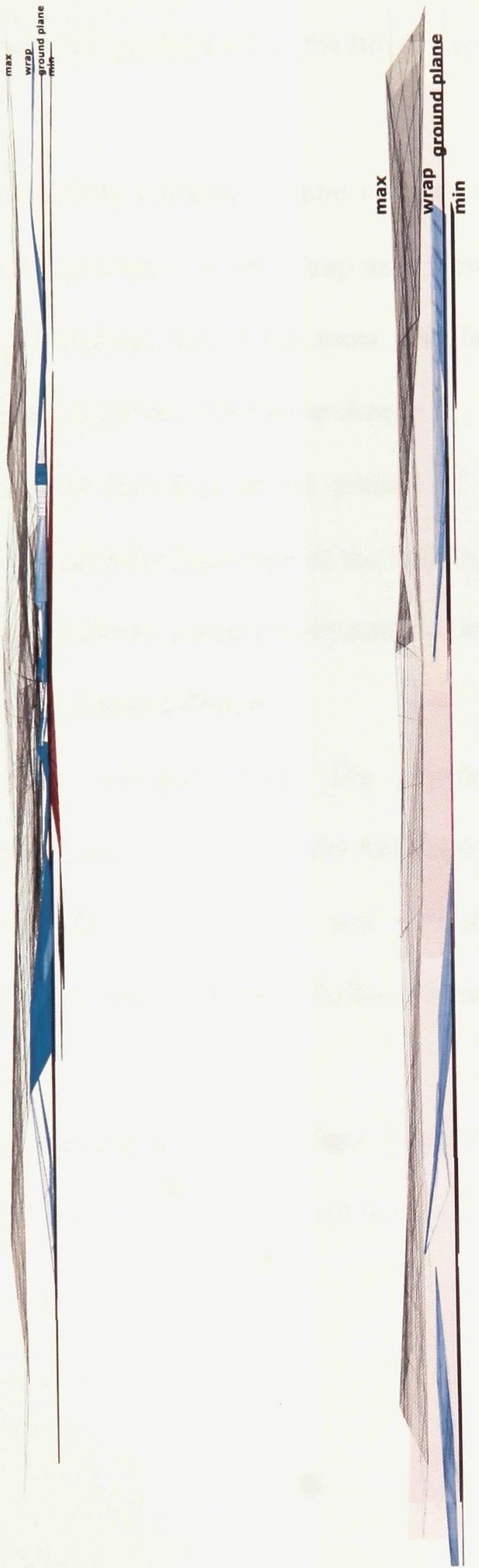

Figure 2.12: Building Envelope. Section. 


\section{Wrap + Existing Building}

Once the city officials have defined the buildings envelopes, the following guidelines explain how to the Wrap may affect the future expansion of a building.

\section{View: Top}

i.1 If any existing building outline is fully covered by a wrap, it must consider the geometry of the Wrap as a New Ground Plane in its future expansions. Further, the Wrap must also be considered as communal/ public space. Refer to i.2 for more details.

i-2. The contour line ( $x, z$ or $y, z$ points) of the wrap must act a plane dictating the exterior landscape of the building. This landscape must allow for entrance and exit points into its attached buildings.

\section{New Ground Plane:}

For existing buildings only. The geometry of the Wrap must be incorporated into the design of the buildings expansion. The Wrap's edge must allow for new entrance and exit points of the building. New Programs may also be inserted below, on top, or incorporate the plane in entirely.

ii.1 If any existing building outline is clear of any wrap, it must only respond to $\mathrm{min} / \max$ building envelopes. 


\section{Wrap + New Building}

For any new construction in under Masterplan II, the Wraps will define where different building types/ programs may be constructed.

\section{View: Top}

iv.1 If three or more branches of a wrap create an interior courtyard shaped space greater than $60 \mathrm{~m} \times 100 \mathrm{~m}$ and less than $80 \times 120 \mathrm{~m}$, a "Play" Development may be added. Refer to Development table below for more information on possible programs.

v.1 If a series of wraps following rule iv.1 are created, the outline of the wrap must be followed as the outline for the construction of an "Activity" Development. Refer to Development table below for more information on possible programs.

vi.1 If a series of wraps overlay a series of buildings; these buildings must be converted into a "Connector" Development. Refer to Development table below for more information on possible programs.

vii. 1 If a plane of a wrap is over-layed on a street; a Play Development must be added on the original street sidewalk. Programs allowed include, bus stop, newspaper kiosks, or pavilions. Refer to Development table below for more information the geometry of the programs.

viii. 1 If no wrap exists, the land may be converted any program Development programs may be inserted, Refer to Development table below for more information on possible programs. 
iv.2. The $\mathrm{z}$ coordinates of the wrap may be manipulated to best accommodate the interior program. Sample: A branch of the wrap may be tilted to convert the plane in to for the interior playing filed.

v.2. The $\mathrm{z}$ coordinates of the wrap may be manipulated to best accommodate the interior program.

vi.2 The $\mathrm{z}$ coordinates of the wrap may be manipulated to best accommodate the interior program.

vii.2 The $\mathrm{z}$ coordinates of the wrap may be manipulated to best accommodate the interior program.

viii. 2 No wrap may be added, but access point onto wraps may be inserted.

\section{Building Types/ Programs}

\begin{tabular}{|c|c|c|c|}
\hline Name & Geometry & Program/ Function & Sample \\
\hline Activity & $\begin{array}{l}\text { Undefined: Reaction contextual } \\
\text { surrounding; Defined in relation } \\
\text { to Wrap + Negative Wrap. }\end{array}$ & $\begin{array}{l}\text { Community Gathering } \\
\text { Space; Commercial; } \\
\text { Community Services }\end{array}$ & $\begin{array}{l}\text { Community Centre; } \\
\text { Cultural Centre; } \\
\text { School: Theatre; } \\
\text { Shopping Mall, } \\
\text { Market; }\end{array}$ \\
\hline Connector & $\begin{array}{l}\text { Non-symmetrical; defined in } \\
\text { relation to Activity, Wrap }+ \\
\text { Negative Wrap. }\end{array}$ & $\begin{array}{l}\text { Commercial; } \\
\text { Residential; Industrial; } \\
\text { Multipurpose }\end{array}$ & $\begin{array}{l}\text { Housing; Office } \\
\text { Space; Factory; } \\
\text { Grocery store. } \\
\text { Commercial space }\end{array}$ \\
\hline Service & $\begin{array}{l}\text { Regulated according to } \\
\text { functional necessities. }\end{array}$ & Community services & $\begin{array}{l}\text { Hospital; Fire } \\
\text { Station; Police } \\
\text { Station }\end{array}$ \\
\hline Play & Linear/ flat geometry & $\begin{array}{l}\text { Outdoor gathering } \\
\text { space/ place }\end{array}$ & $\begin{array}{l}\text { Playing fields; } \\
\text { Soccer; Basketball; } \\
\text { Tennis; Children's } \\
\text { Park }\end{array}$ \\
\hline Bits & Small; undefined & Commercial & $\begin{array}{l}\text { Restaurants, Stores, } \\
\text { Pavilions, Kiosks }\end{array}$ \\
\hline $\begin{array}{l}\text { Response- } \\
\text { Surface }\end{array}$ & $\begin{array}{l}\text { Non-symmetrical; Attach to } \\
\text { Wrap }\end{array}$ & $\begin{array}{l}\text { A connecting path } \\
\text { between any two } \\
\text { separated surfaces. }\end{array}$ & $\begin{array}{l}\text { Pathway; Walkway; } \\
\text { Staircase }\end{array}$ \\
\hline In-Between & $\begin{array}{l}\text { Inhabit space between Wrap + } \\
\text { Negative Wrap. }\end{array}$ & Residential; Commercial & $\begin{array}{l}\text { House, Apartment, } \\
\text { Multipurpose. }\end{array}$ \\
\hline
\end{tabular}


Activity

- The distance between any Activity program sharing the same function cannot exceed 3 kilometres in diameter.

- The distance between any Activity program, sharing the same function cannot be closer than 2 kilometres in diameter.

\section{Connector}

- The distance between any Activity program sharing the same function cannot exceed 3 kilometres in diameter.

- The distance between any Activity program, sharing the same function cannot be closer than 2 kilometres in diameter.

Service

- To be located by city officials

- The distance between Fire Stations cannot exceed 3 kilometres in diameter. Total number of Fire stations for city cannot exceed three.

- The distance between Police Stations cannot exceed 5 kilometres in diameter. Total number of Police Stations for the city cannot exceed two.

- The city cannot have more than one hospital.

- The distance between private medical clinics is undefined. To be located in any Connector Development

Play

- The distance between soccer fields cannot exceed one kilometre in diameter.

- A group of soccer fields cannot exceed 3 fields. 
- Every public park must contain a soccer, basketball and tennis facilities.

o Private parks do not have to follow regulation sizes of any sports.

- There is not restriction in the distance between basketball and tennis courts.

- Children Parks must follow National park guidelines.

Bits

- The distance between bus stations along the same line cannot exceed 300 metres.

- The distance between bus stations (the network as a whole) cannot exceed 200 metres in diameter.

- The location of Restaurants and small commercial facilities must be incorporated in Connector, Activity and Service Developments.

- Newspaper kiosks may be inserted where appropriate.

Response Surface

- Response surfaces may extend or cut-into any Wrap + Negative Wrap to facilitate the accessibility between any two surfaces.

In-Between

- In the development of any area of the city, there may contain small or large areas that do not follow into any of the above guidelines. The InBetween Development is a geometrically undefined development, with no restrictions, except to follow the Density Percentage.

- The purpose of the In-Between is to develop areas of the city in "trial and error" manner. 


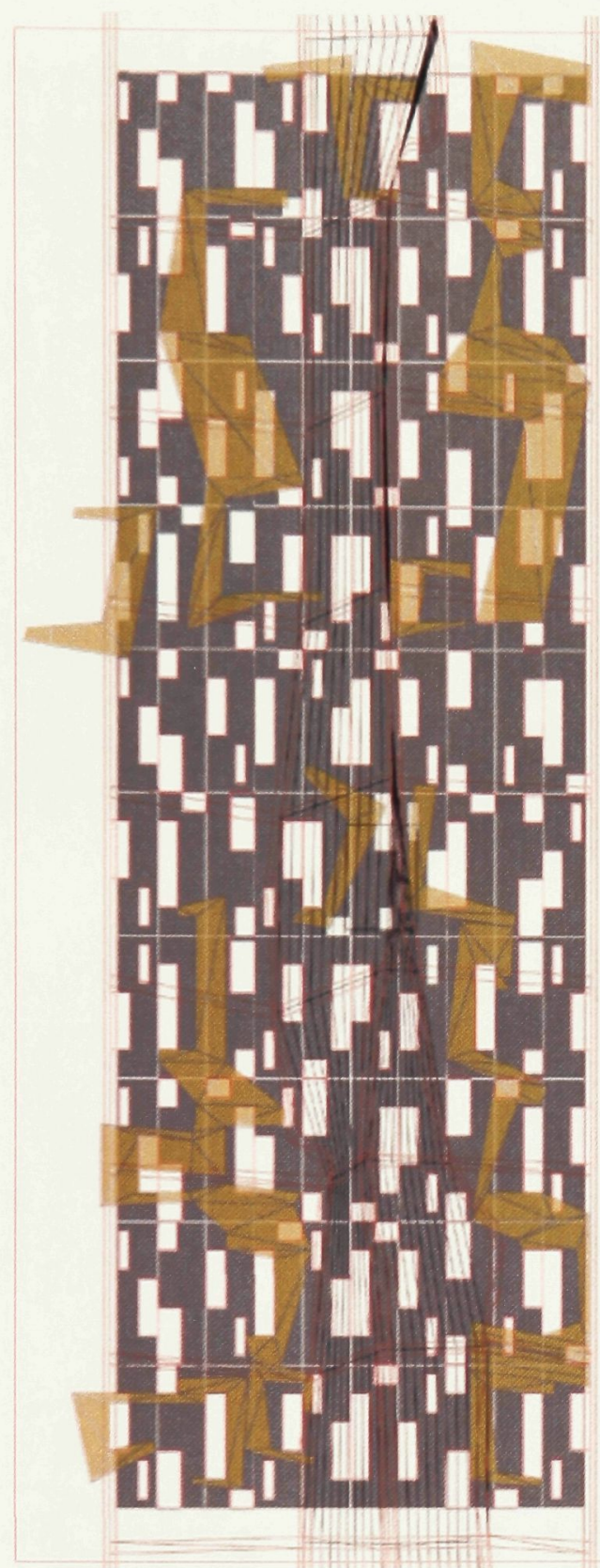

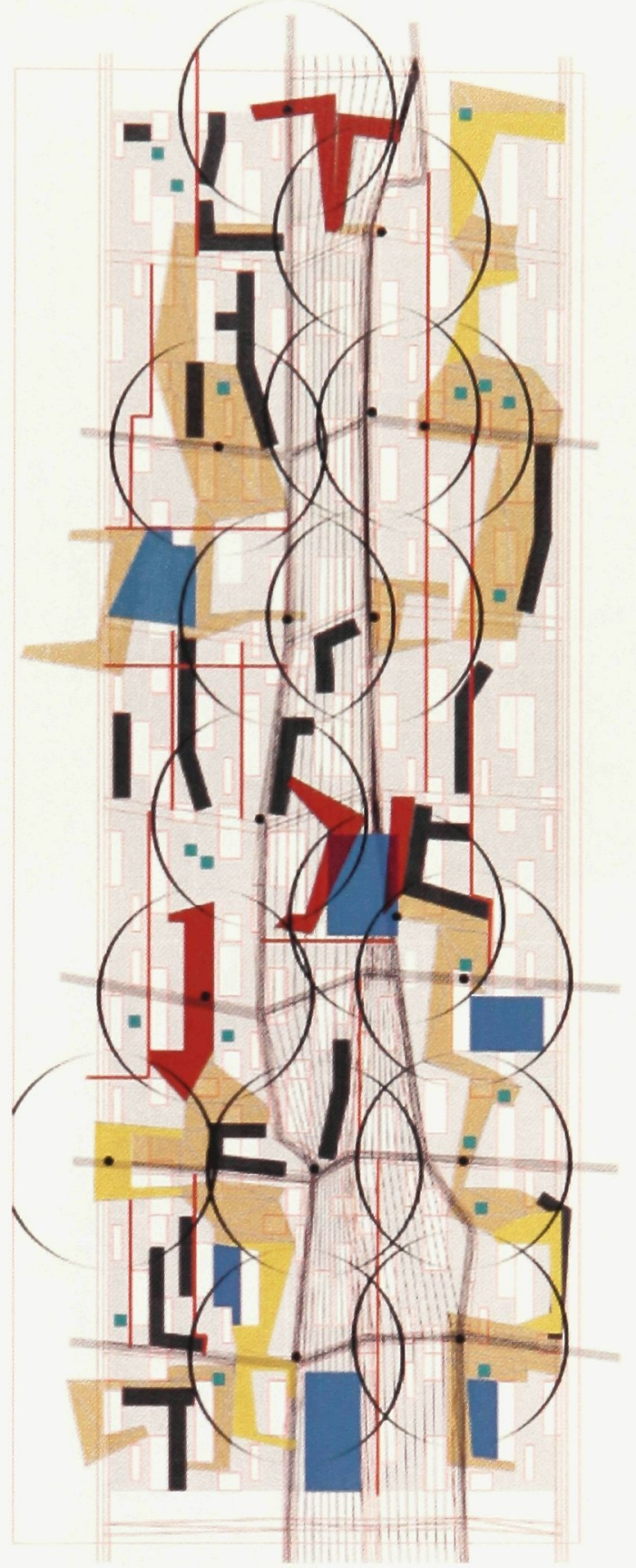

Wrap overlay 2

Arrangement of new buildings and programs following "Development" chart

Figure 2.13: Growth of a high-density neighborhood. 

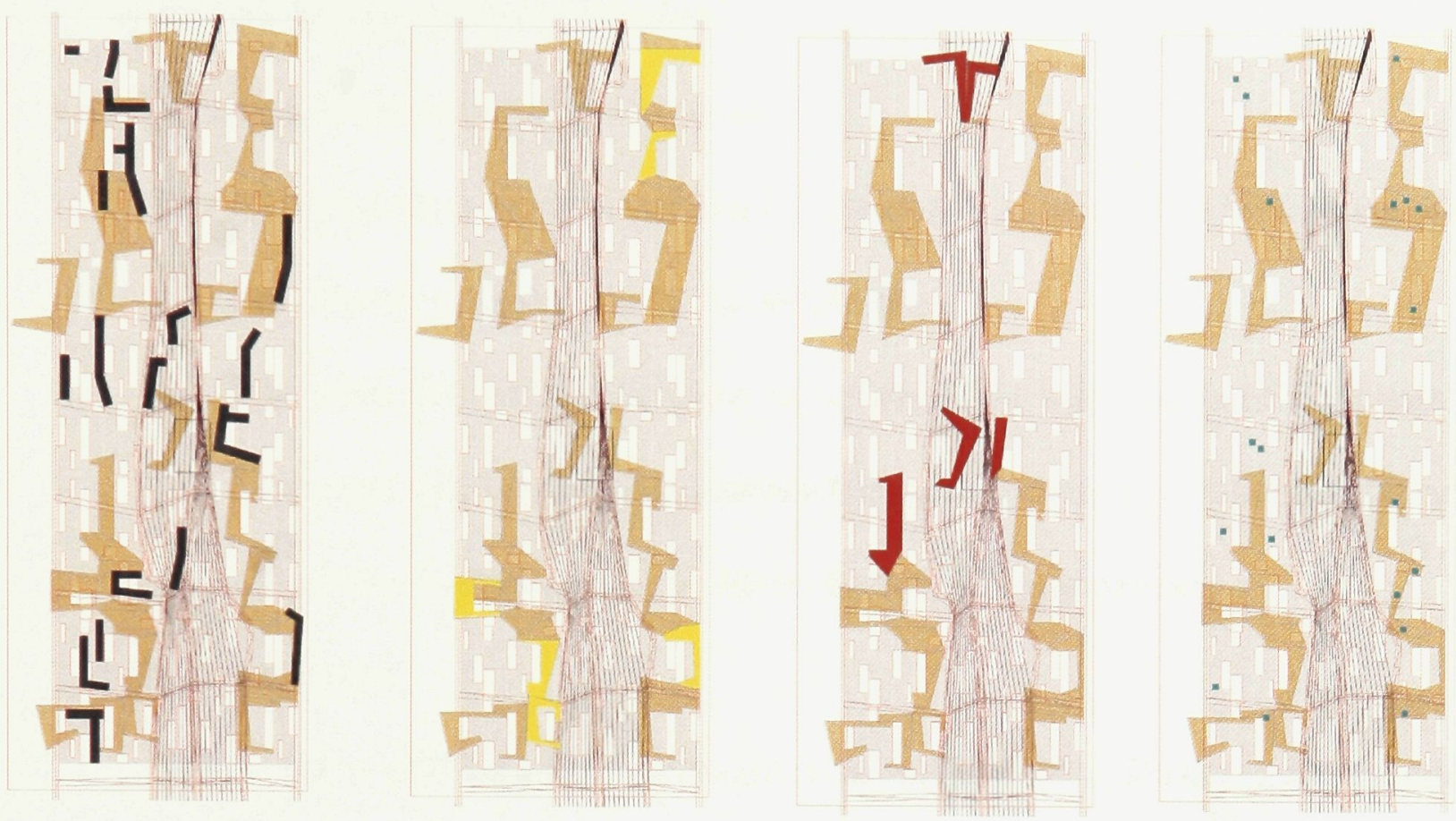

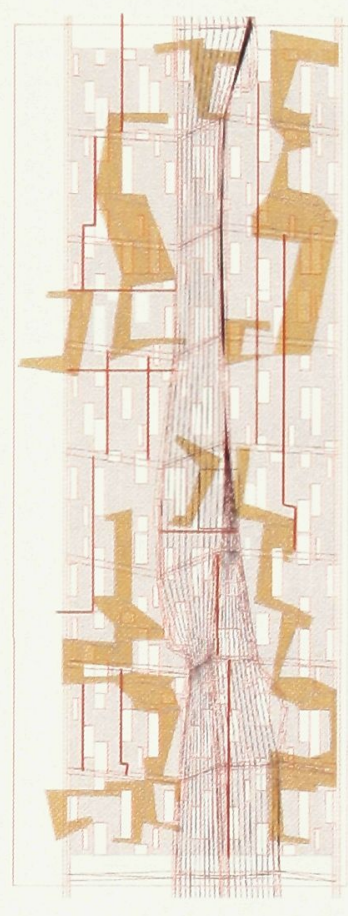

New Roadway

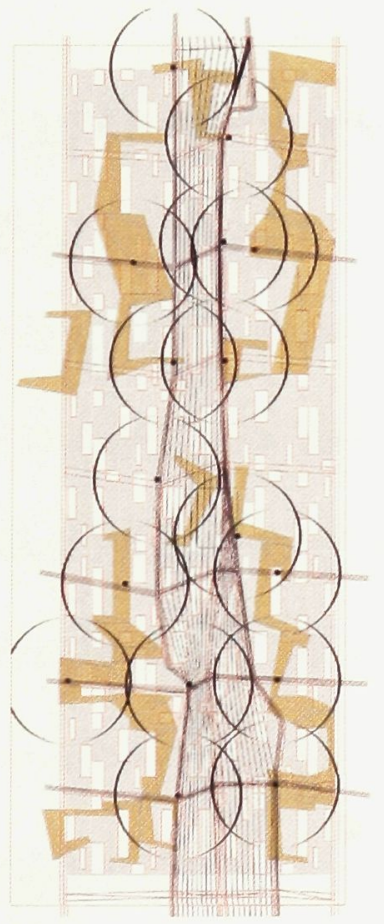

Bus Stations

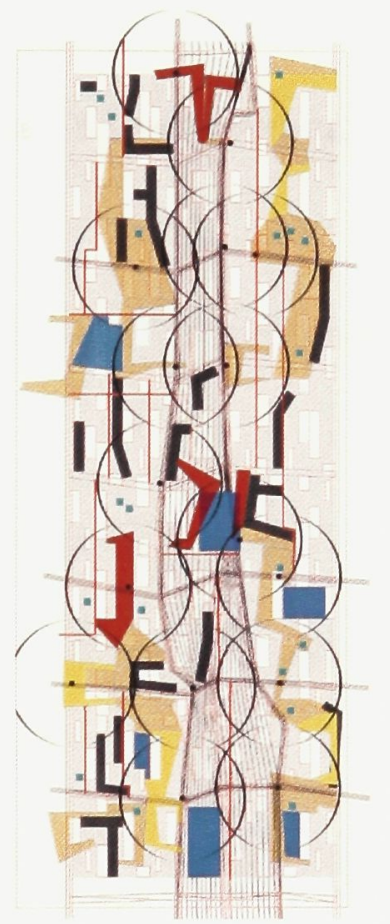

Phase 2 Masterplan of Site

Figure 2.14: Layers of high-density neighborhood. 


\section{Low Density}

- The planning in Masterplan I was followed by the different density patterns derived by mixing the three different lot sizes.

- The planning in Phase II can go in two ways

i. Continue the patterns from Phase I. However, no more than $50 \%$ of the all low-density neighborhoods can follow this.

ii. The other $50 \%$ of the land must be developed by the creation of a dynamic landscape that houses and commercial space will have to either inhabit or respond to in their design. Refer to the following guidelines:

Folding Landscape

i. Each $500 \times 500 \mathrm{~m}$ piece will begin with the plan of a density pattern from Phase I.

ii. Lots are to range from $60-1000 \mathrm{~m}^{2}$, and residential units are not to exceed $80 \mathrm{~m}^{2}$ of usable floor space.

iii. Vectored fold lines are to be drawn for the placement for new roadways to replace the existing parallel format.

a. In plan, these lines must triangulate the square land

iv. At each vectored point, new heights are to be determined, ranging between 06 metres in height from the ground plane

v. The layouts of house lots are to rotate according to fold lines.

a. In section, certain lots will be overlapped with new folded landscape

vi. If developer or architect is planning a development larger than $500 \times 500 \mathrm{~m}$, the plan must be broken into $500 \times 500$ blocks. 


\begin{tabular}{|c|c|c|}
\hline Overlapped & Partial Overlap & Non-Overlapped \\
\hline $\begin{array}{l}\text { If an entire lot is overlapped by } \\
\text { the new landscape, building must } \\
\text { be built on top of new ground } \\
\text { plane. } \\
\text { Overlapped lots may only be } \\
\text { zoned for residential programs. }\end{array}$ & $\begin{array}{l}\text { If any lot is only partially } \\
\text { overlapped, the lost may not be } \\
\text { considered for residential use. } \\
\text { Small commercial space may be } \\
\text { zoned for the remain lot } \\
\text { dimension not overlapped. }\end{array}$ & $\begin{array}{l}\text { If lot is not overlapped by new } \\
\text { landscape, two storey building } \\
\text { unit must be built. } \\
90 \% \text { of buildings are to be zoned } \\
\text { for residential programs in both } \\
\text { storeys of floor space } \\
10 \% \text { of building must locate } \\
\text { commercial space in lower floor, } \\
\text { and residential on second } \\
\text { If lot size is not overlapped by } \\
\text { new landscape, but has one side } \\
\text { of the perimeter adjacent to a hill } \\
\text { and a "Overlapped" condition, the } \\
\text { design of building must be } \\
\text { integrated into the design of } \\
\text { "Overlapped" condition. } \\
\text { Therefore, lot may be zoned up to } \\
3 \text { storeys in height to attach to } \\
\text { "Overlapped" dwelling. } \\
\text { If the building height is } 3 \text { storeys } \\
\text { in height, the ground floor space } \\
\text { may be zoned as a dual retail } \\
\text { commercial and residential space. }\end{array}$ \\
\hline
\end{tabular}

Notes:

3 Storey buildings

- The purpose to commercialize the ground plane on 3 storey buildings is to allow citizens to operate small retail spaces as a part of their dwelling. Retail space must face street. 


\section{Appendix I}

\section{Llanos del Solar}

\section{Project Requirements}

\section{Initial Goals}

The series of goals and program requirements listed below were developed to create a source of reference for the process of the design proposal. The list is a source of reference.

\section{Section I Pre-Year 0}

Citizens: $\quad 70 \%$ are low-income citizens working in surrounding cities and industrial areas, including the southern communas of Gran Santiago.

$30 \%$ are middle-class citizens working within the city of Llanos del Solar, but half also traveling daily to adjacent cities and Gran Santiago. ${ }^{38}$

Analysis of Llanos del Solar's growth pattern

- Map of the city's contextual surroundings in marking adjacent cities, infrastructure (road, rail) and economic/ industrial forces.

- The map must demonstrate how the city will grow over time. (Is it a linear growth, moving from the south towards the north? Or Vice a versa? Is it a clustered growth where each cluster expands over time connecting to others?)

The growth pattern must be broken down into phases.

i. Phase 1: Year 0-5

ii. Phase 2: Year 5-20

iii. Phase 3: Year 20+

38 The percentages given are assumptions created for this project. The actual percentage for Llanos del Solar is $100 \%$ low-income, however, I wish to add middle-class citizens to this design project in order to create a more diverse cultural and social interaction between citizens. 
Phase 1 Masterplan

Goal:

- Create a foundational physical fabric for the city with all necessary public services and infrastructures for future developments.

Primary Factors:

- A city mandate and vision.

- Sufficient housing for a population of ten thousand $(10,000)$ inhabitants.

- Integration of mass public transportation system into masterplan

- Infrastructure to force a lower private vehicle/ citizen ratio. National Average: 147 vehicles/ 1000 citizens.

- Planning and bylaws to reject traditional North American suburban planning.

- Plan must not allow for uncontrollable urban sprawl.

- The planning, layout and design of Phase I the Stage 1 Masterplan must set out to complete a set of infrastructural, housing, and commercial zoning bylaws.

There is no restrictions in the "style" of planning, however, the plan must consider how future developments will be integrated.

\section{Section II Year 0 - 5}

\section{Construction}

Goal:

- Construction of Phase 1 Masterplan

o Install all necessary infrastructural needs for future growth.

\section{Section III Year 5 - 15}

Phase 2 Masterplan (for years 5-20)

Goal: 
- Analyze social spatialization that exists in the city of Llanos Solar.

- Create a Phase 2 Masterplan for the city's development reflecting the results of the analysis.

- Integrated mass public transportation system within the planning and design of city morphology.

Primary Factors:

- Sufficient housing and infrastructure for a population of fifty thousand $(70,000)$ inhabitants by year 20 .

- Integration of mass public transportation system into masterplan

o Infrastructure to force a lower private vehicle/ citizen ratio. National Average: 147 vehicles/ 1000 citizens.

- Planning and bylaws to reject traditional North American suburban planning.

o Plan must not allow for urban sprawl.

- The planning, layout and design of the Phase 2 Masterplan must reflect the existing city morphology in not only developing unused land, but as well as redeveloping the built environment.

- There is no restrictions in the "style" of planning, however, the plan must consider how past and future developments will be integrated.

- Outline of housing and commercial ownership laws for all neighborhood types.

- Must integrate how the city's infrastructure will bond with adjacent communities and cities: Batuco, Lampa, Colina, Estacion Colina.

- Integration of Railway

\section{Section IV Year 20+}

Phase 3 Masterplan (for years 20+)

Goal:

- Analyze social spatialization that exists in the city of Llanos del Solar. 
- Create a Phase 3 Masterplan for the city's development reflecting the results of the analysis.

- Integrated mass public transportation system within the planning and design of city morphology.

- An official masterplan responding to the lessons learned from Phases 1 through 4

Primary Factors:

- Sufficient housing and infrastructure for a population of seventy thousand $(70,000)$ inhabitants by year 20 .

- Integration of mass public transportation system into masterplan

o Infrastructure to force a lower private vehicle/ citizen ratio. National Average: 147 vehicles/ 1000 citizens.

- Planning and bylaws to reject traditional North American suburban planning.

o Plan must not allow for urban sprawl.

- The planning, layout and design of the Phase 3 Masterplan must reflect the existing city morphology in not only developing unused land, but as well as redeveloping the built environment.

- There is no restrictions in the "style" of planning, however, the plan must consider how past and future developments will be integrated.

- Outline of housing and commercial ownership laws for all neighborhood types.

- Must integrate how the city's infrastructure will bond with adjacent communities and cities: Batuco, Lampa, Colina, Estacion Colina.

- Integration of Railway

\section{Restrictions:}

Low + High Density Zoning Density

Minimum Requirements. Some values may change if planning allow for a higher floor space for certain programs. 
- Low Density:
a. Residential
$70 \%$
b. Retail + Cultural
$5 \%$
c. Public Services
$3 \%$
d. Public Space + Parks
$15 \%$
e. Infrastructure
$7 \%$

- High Density:

f. Residential $\quad 53 \%$

g. Retail + Cultural $\quad 10 \%$

h. Public Services $\quad 5 \%$

i. Public Space + Parks 20\%

j. Road Infrastructure $\quad 12 \%$

Note: There are no specific percentages for mid-density zoning.

Housing:

a. All private houses will have a value between 800 and 1100 UF. (Between $\$ 30,000$ and $\$ 37,500 \mathrm{CDN}$ )

b. Therefore: ALL lot sizes must range between 60 and 100 square metres, and houses can only have between of 50 to 80 square metres of usable floor space. 


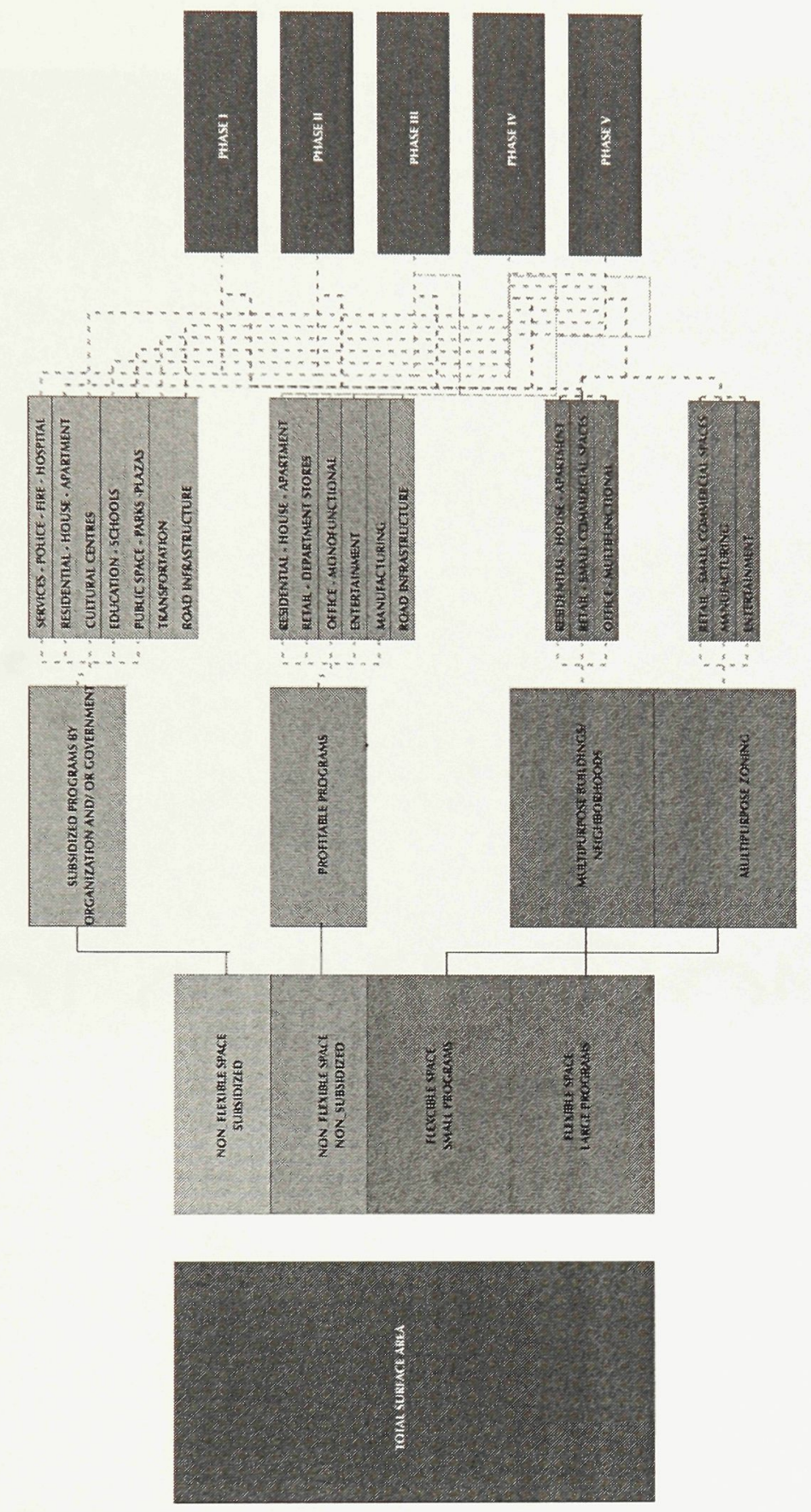

Figure 3.4: Flexible/ Non Flexible Growth.

The goal for land-use is to create a $60 \%$ of all land-use in high-density neighborhoods as flexible as possible. In other words, $60 \%$ of all floor space is planned as multipurpose. $40 \%$ is left for non-flexible spaces, with half being built for low-income families with support from the municipal government, and the other half for profitable space. 
Appendix II

Case Study: Curitiba, Brazil

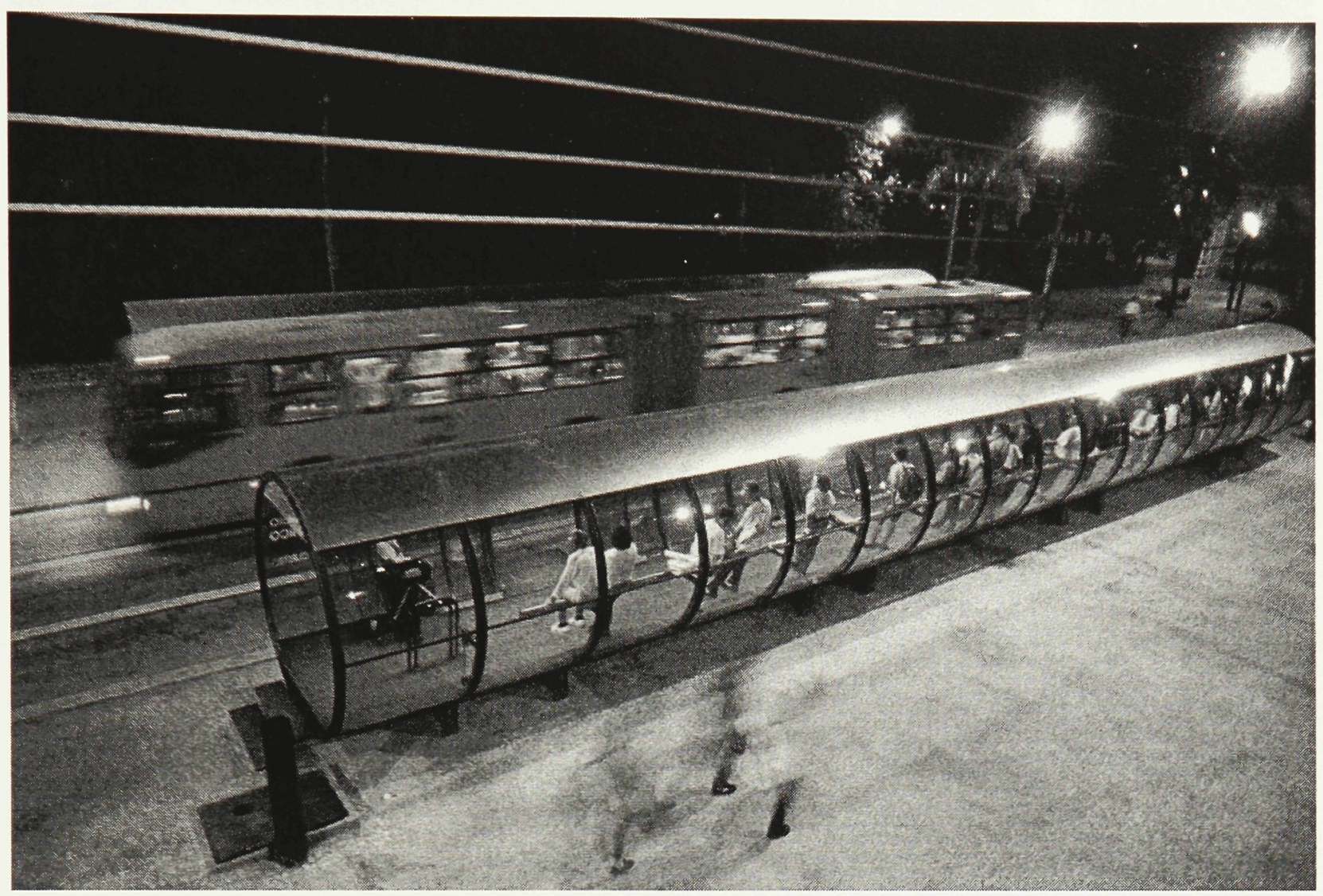




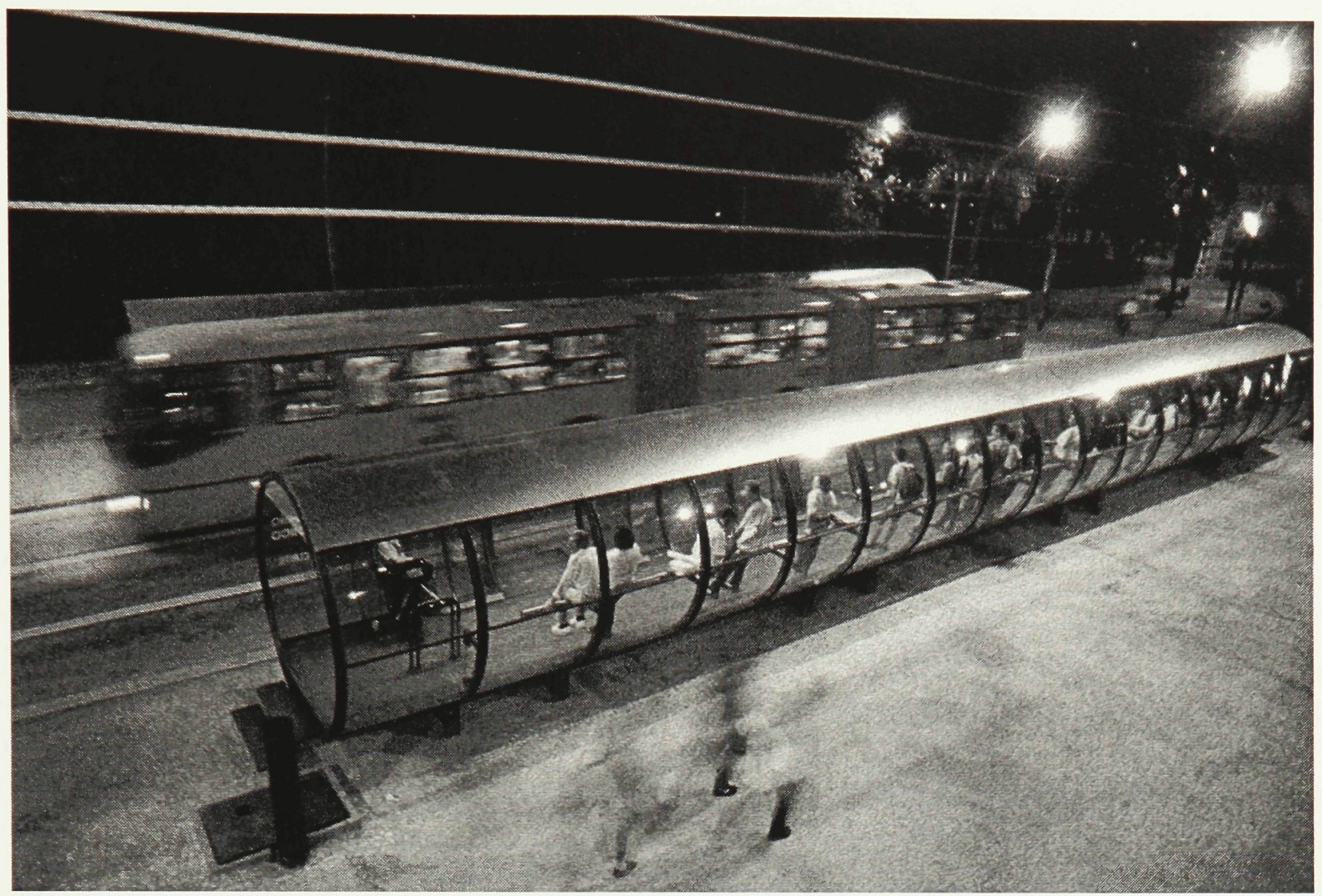

Figure 4.1: Curitiba Bus Station.

(Source: Municipal Government of Curitiba. $<\underline{\text { http://www.curitiba.pr.gov.br/ }>\text { ) }}$

Transport system, terminals, stations, spaces defined by escalators and moveable walkways, and great waiting rooms now transport citizens from one point to another, stopping, passing through, and binding all the points within our environment. In the vast metropolises of the world, mass transportation has come to integrate highly complex matrices of lines and nodes, serving citizens and tourists to all accesses and speeds of our cities. The concrete walls of permanence no longer define these spaces; rather is precisely the movement that now defines these spaces. Each station of a system has become the identity of its surroundings in breaking the city into a series of geometric patterns. They have become a new of form of "place" responding to the necessities of our contemporary rituals. Covered by mass media, graphics, charts, maps, timetables, and yellow safety lines, these nodes of transportation no longer need be considered displaced from the city morphology, as a disjunction - or a separated island. They are an integral layer within the 
realities of the city. The bus stop, one of the infinite different city typologies that we inhabit everyday, is a typology that is multi-dimensional - it has its own properties but is virtually connected to a network of other bus stops. They are separated from the historical network of social spaces; they are in fact another layer within the city, with it sown cycles of time creating a network within itself, working within the existing network of physical boundaries. The continuous city that we view from the outer space has become to large to understand all the possible relationships whereas mass transport has begun to anchor the city and give the possibility for not only allowing for a new form of mapping the city, but as well as giving rise to a new form of place-myth differentiation. Transportation, in this sense is no longer considered as an additive to the city, but rather a metaphor of a spatial trajectory. De Certeau explains that mass transportation may be a form of metaphor; it organizes and link places where they create sentences and narratives. The narratives, the sequence of events contain a spatial axis where the metaphor is able to regulate and restrain the boundaries of interpretation and perception. ${ }^{39}$ One goes here to here, surrounded by relations coordinated by the bodies' relationship.

During every journey there is a story, a spatial practice. The journey is a geography of events organized by relationships (past and present) not displacing or transposing, but mapping the real into a transitory sequence. Boundaries outlining places (whether a building, community or city) must not be regarded as the limit of its processes, but as a boundary to be traversed. Physical Boundaries may define the routes of passage, but is it movement that defines and constitutes the metaphorical boundaries leading to identity. Boundaries are in away the tracing or residue of the movement.

39 Michel de Certeau. The Practice of Everyday Life. Berkeley: University of California Press, 1984. 
Movement is no longer indexed to position. "Rather position emerges from movement, from a relation of movement to itself., ${ }^{, 40}$

Two of the most important systems of transport are the metro and the bus. Though the spatiality of the two is very different, they both have the ability to shape the space of the city in their own way. The city of Curitiba, Brazil has introduced and exemplified the possibilities of using applying the structure of both systems into a single highly developed bus transportation system. Curitiba today, is the result of over fifty years of trial and error based on ratifying the possibilities of relating city growth and urbanization with the flow of movement. Historically, Latin American cities follow a centralized planning structure where growth radiates outwards from the city core into a network of squatter settlements. Where most cities define mass transportation by the city's roads infrastructure, Curitiba's pattern of growth is defined by its transportation system

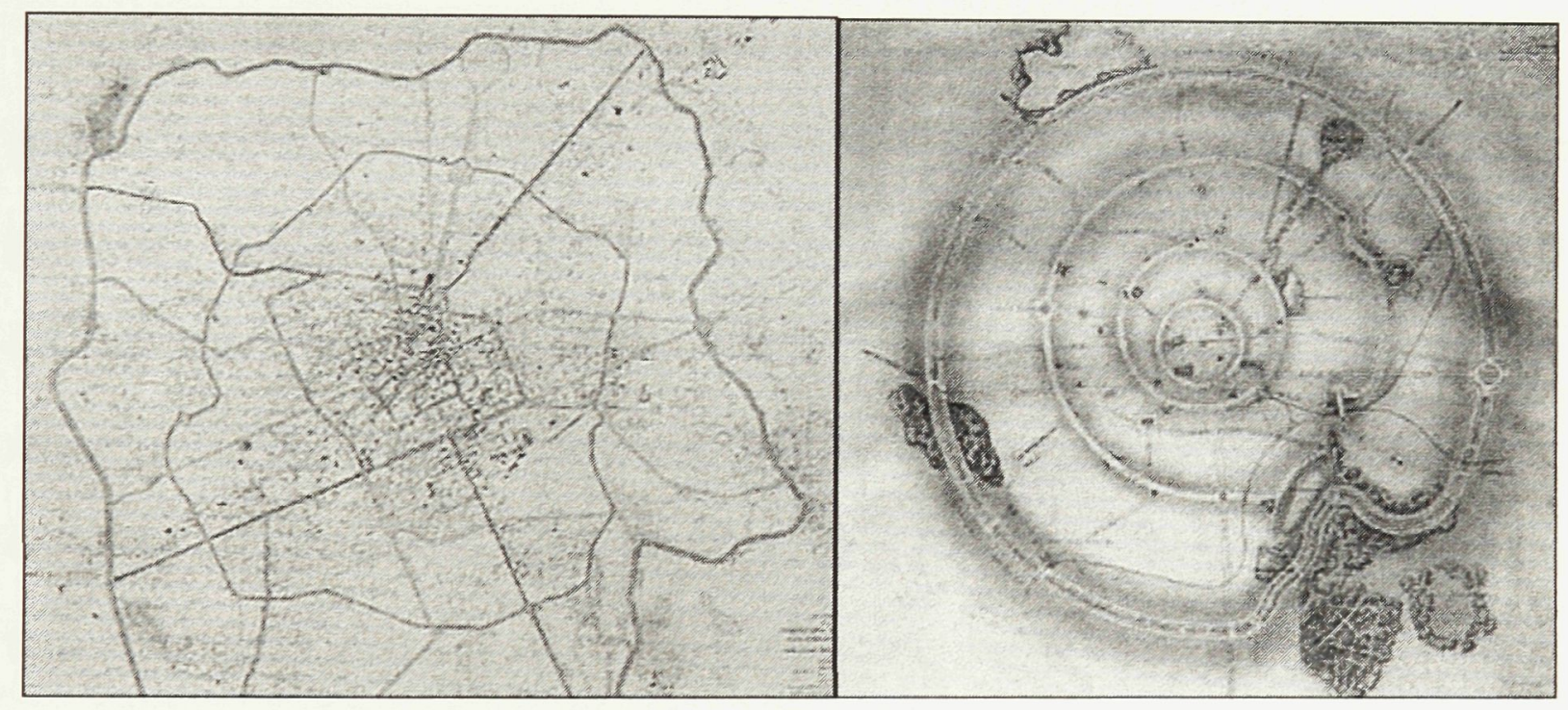

Figure 4.2 \& 4.3: Agache Plan for Curitiba, 1941.

(Source: Municipal Government of Curitiba. $<\underline{\text { http: } / / w w w . c u r i t i b a . p r . g o v . b r} />$ ) 
The first initiative that began this urbanization in Curitiba was the urban masterplan by French modernist planner, Alfred Agache, founder of the French Urban Society in 1941. Latin America has followed and pursued urban utopian ideals from western cultures, perhaps even more than the rest of the world. Latin America has swallowed the modernist theories during the post-war era, and now it is swallowing the North American trends of New Urbanism. "Nowhere else have modernistic urban theories, above all Le Corbusier's Ville Radieuse, controlled the minds of practicing architects and urban designers as much as in Latin America. ${ }^{41 "}$ Colombia, Venezuela, Argentina, Brazil and Chile are at the forefront of this trend where cities such as Cidade dos Motores, Brazil was envisioned by Jose Luis Sert and Paul Lester Wiener in 1942; Brasilia, Brazil in 1957-196w by Lucio Costa and Oscar Niemeyer; in Chile, the Portales neighborhood in 1959, and Emilio Duhart's UN Headquarters in Santiago in 1966.

The plan for Curitiba, much like Brasilia followed the major assumptions and goals of the Ville Radieuse. First, a completed closed plan, rigid structure that would not allow for future growth to eliminate the problems of industrial cities with their growth deficiencies. Second, old city patterns of high density housing and wondering pathways are to be rejected, instead be replaced by large residential units soaring within a landscape of great gardens. Third, the city is to be divided and sub divided according to function that will allow for ease of automotive transportation. The 1934 plan by Alfred Agache concentrated on the above goals, and embraced the rise of the automobile. His plan suggested creating large avenues that would radiate from the central core of the city, adequate housing, zoning and technical standards for the city's physical urban growth.

41 Francisco Bullrich. New Directions in Latin American Architecture. New York, NY : George Brazillier, Inc, 1969. 
The plan was never fully implemented, but the creation of the large avenues were formed, and it was not for another thirty years that officials of Curitiba decided to actually complete a master plan that would guide the city's rapid population growth. To guide this development, the city administration in 1965 founded the Curitiba Research and Urban Planning Institute.

To initiate this new masterplan, the state commissioned an international competition. Jaime Lerner, a young architect and a member of the winning entry, took control of this developmental process, and has been looked upon as the reason for the city's success. He "embarked on a path that took control of that gained him worldwide respect and admiration for his visionary leadership in transforming Curitiba into what planners call the most environmentally advanced urban area on Earth. ${ }^{, 42}$
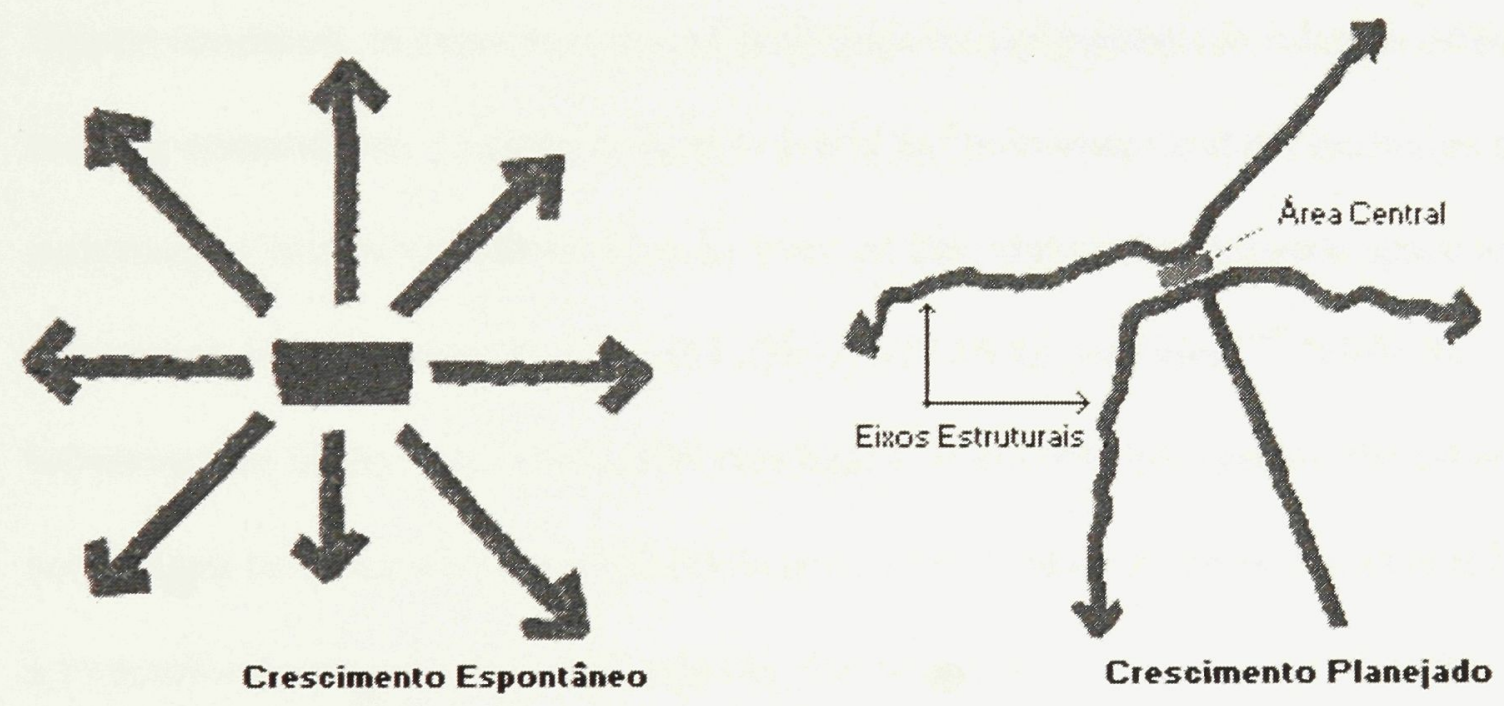

Figure 4.4: Spontaneous Growth Diagram. (Source: Municipal Government of Curitiba. $<\underline{\text { http://www.curitiba.pr.gov.br/ }>\text { ) }}$

Figure 4.5: Planned Growth Diagram. (Source: Municipal Government of Curitiba. $<$ http://www.curitiba.pr.gov.br/>)

42 Miriam Knight. Vision + Participation $=$ A City that Works. Community ConneXion $<\mathrm{http}$ ://www.newconnexion.net/article/09-00/vision.html > 
In a recent interview, Jaime Lerner describes his ideology of city growth as "keep it simple. Begin it now. Don't rush to have all the answers. ${ }^{43}$ " Lerner continues by stating city officials in general tend to project tragic situation - thinking about side effects of a project, rather than applying and learning. "In the 1970's most cities were pouring money into public work and working for the car. We do not work for cars. We work for the people. If a city treats people with respect, they will respect the city. ${ }^{44}$

In all other major Latin American cities, architects and planners continued to follow modernist ideals, or in some cases, they followed no ideal or structure at all such in the case of Santiago, Chile during the Pinochet regime. Santiago's administration concentrated on creating sufficient housing for the population, not on how the citizens would travel within these new large housing projects. The planners of Curitiba used a flipped condition, in experimenting in how mass transportation can relay its effects in housing construction. Curitiba considers travel as "movement and the exchange between activities...Curitiba's planning focuses more on the relationship between space and movement. It emphasizes the dynamic features of urban activities. ${ }^{, 45}$ While the infrastructure of the new master plan was based on the new bus system, the urban fabric would then be structured around the transportation. In general terms, the plan is based on a hierarchical structure of a road network that would allow for the control of the vehicular and population density throughout the city. Santiago on the other hand, with a stronger economy decided to install subway systems to accommodate traffic, but Curitiba did not have an economy to sustain such an investment. Curitiba instead constructed five

\footnotetext{
43 Ibid.

44 Ibid.

45 Jonas Rabinovitch, John Hoehn. A Sustainable Urban Transportation System: The "Surface Metro" in Curitiba, Brazil. <http://www.wisc.edu/epat/.energy/.metro/.entire.html>
} 
structural corridors in order to re-direct the growth of city along these arteries. This redirection of growth is based on the notion of density control and avoiding traffic congestion within the central historic city. However, this is not the same as a central decentralization structure where sprawl becomes uncontrollable and boundaries become blurred, rather these arterial roads are foundational physical boundaries.

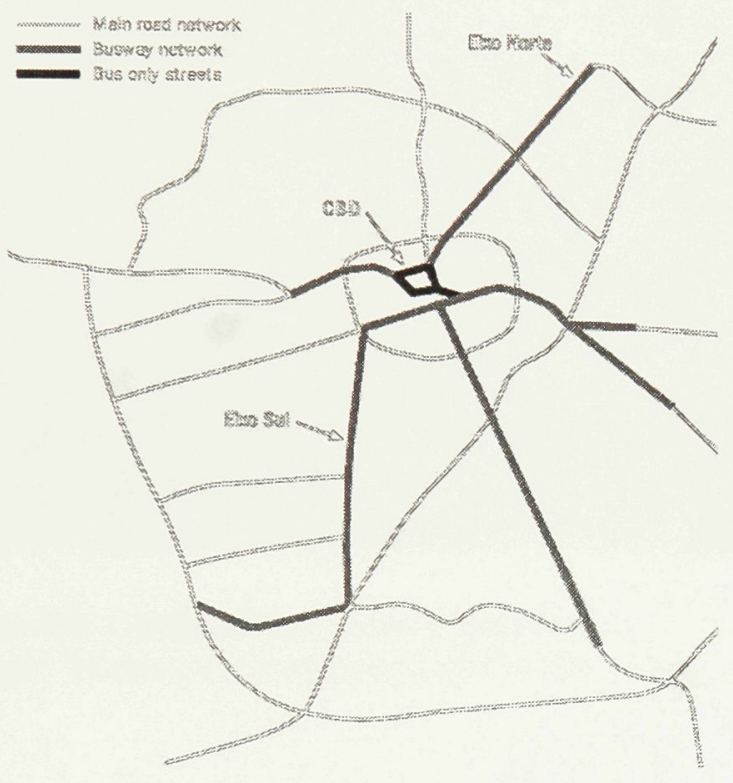

Figure 4.6: Curitiba Arterial Growth Corridors. (Source: Municipal Government of Curitiba. $<\underline{\text { http://www curitiba.pr.gov.br/ }>\text { ) }}$

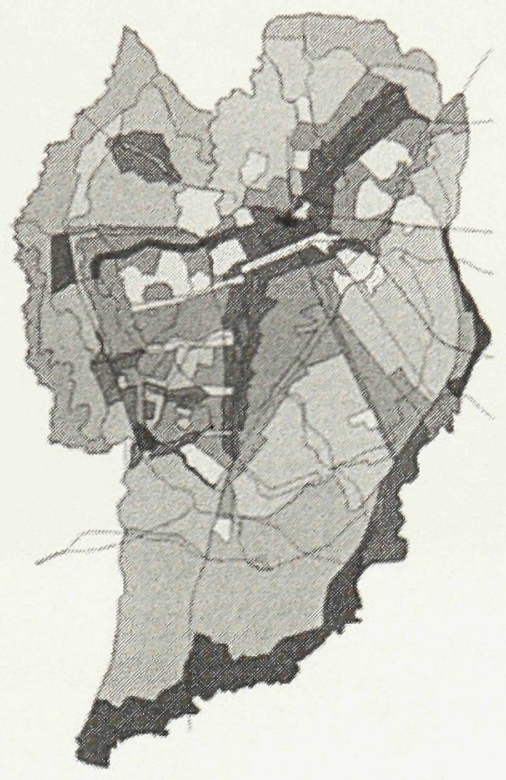

Figure 4.7: Curitiba Land-use. (Source: Municipal Government of Curitiba. $<$ http://www.curitiba.pr.gov.br/>) 


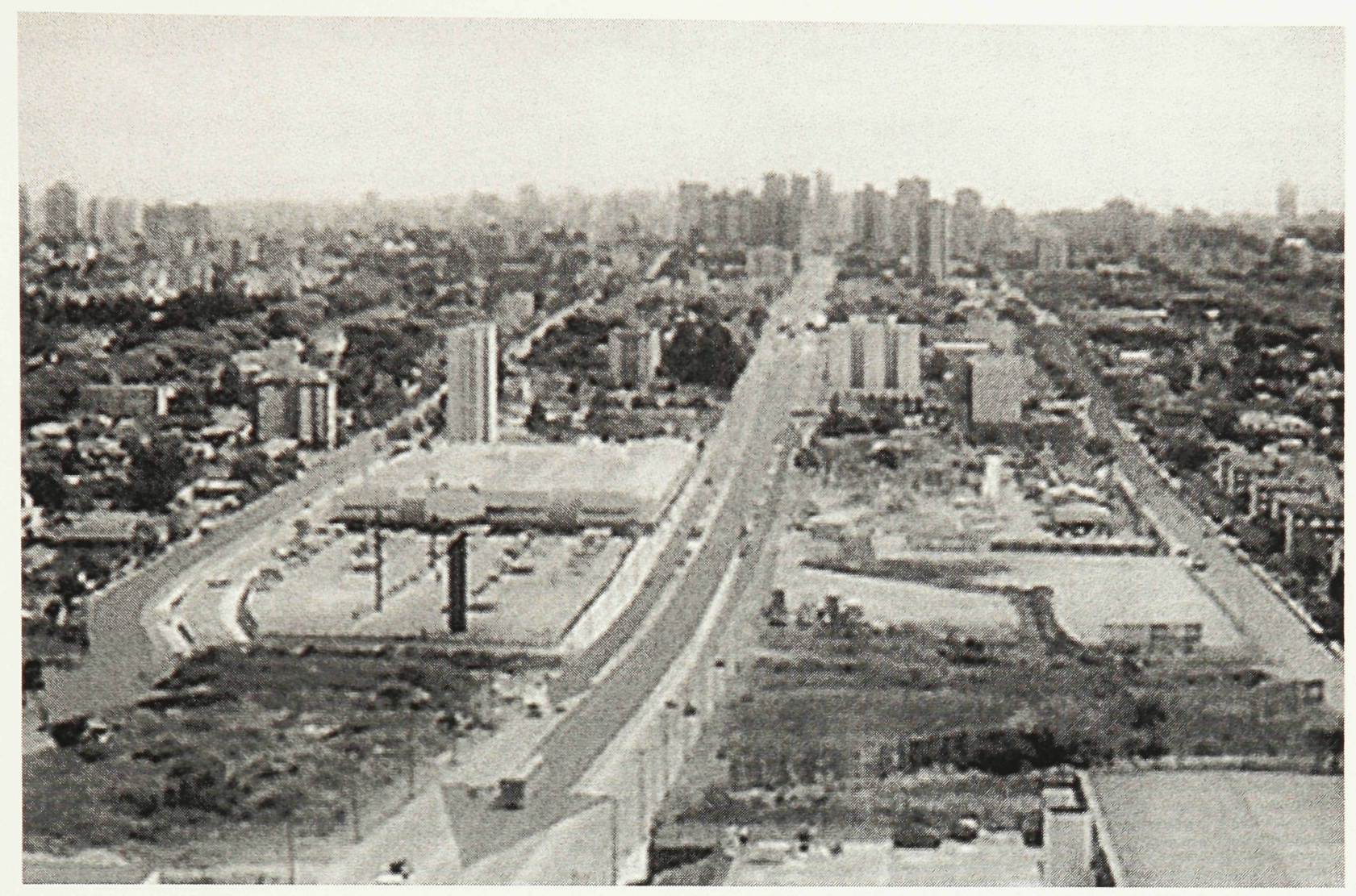

Figure 4.8: Curitiba Road Infrastructure.

(Source: Municipal Government of Curitiba. <http://www.curitiba.pr.gov.br/>)

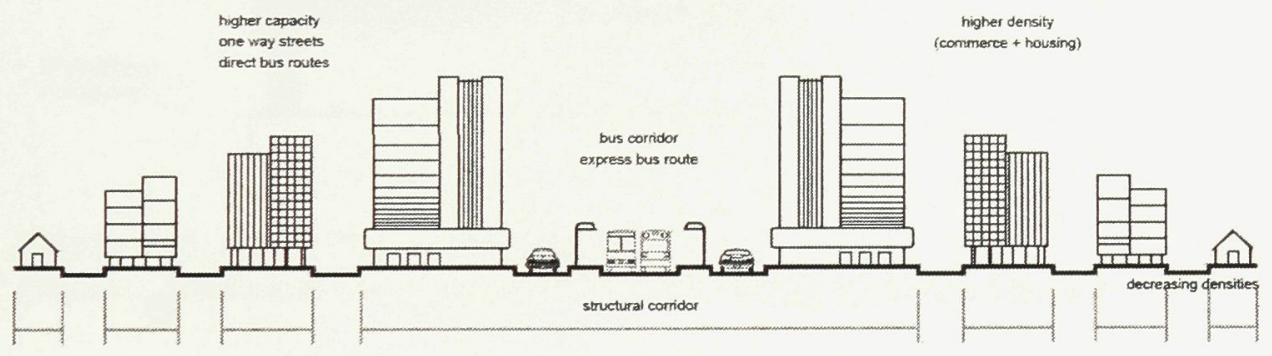

Figure 4.9: Section, Curitiba Growth Corridor.

(Source: Municipal Government of Curitiba. <http://www.curitiba.pr.gov.br/>) 


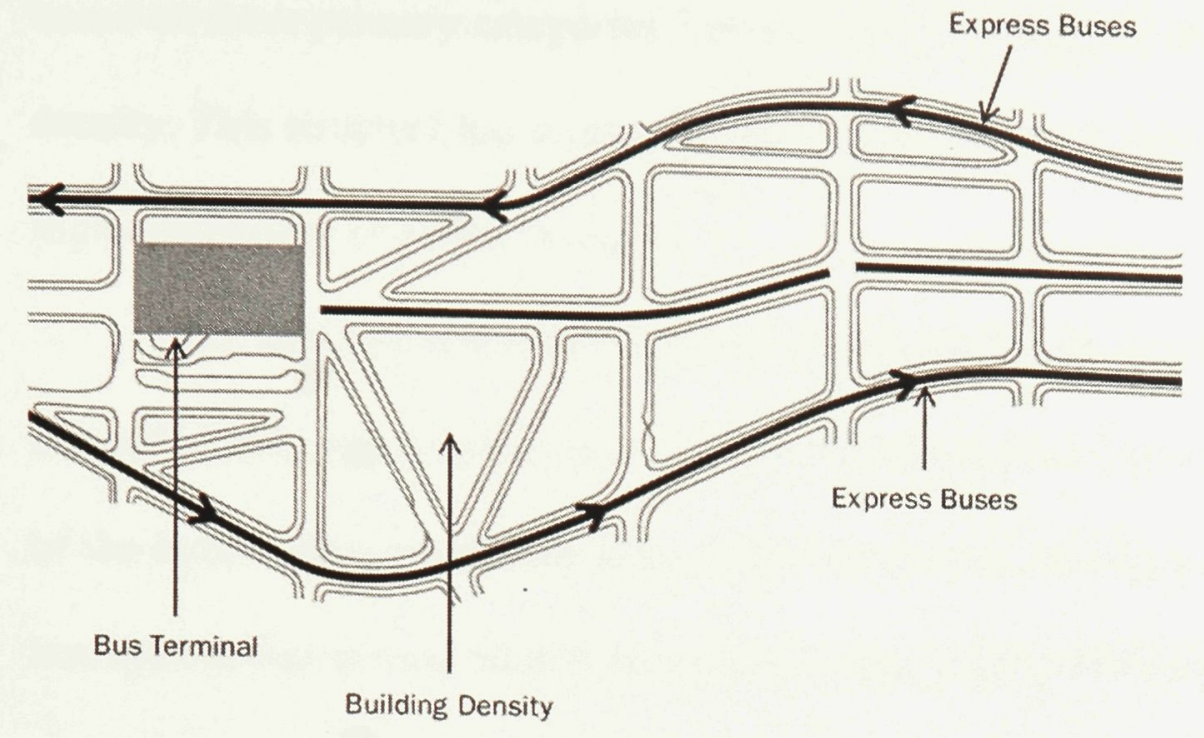

(

Figure 4.10: Plan, Curitiba Growth Corridor.

(Source: Municipal Government of Curitiba. $<\underline{\text { http: } / / w w w . c u r i t i b a . p r . g o v . b r}>$ )

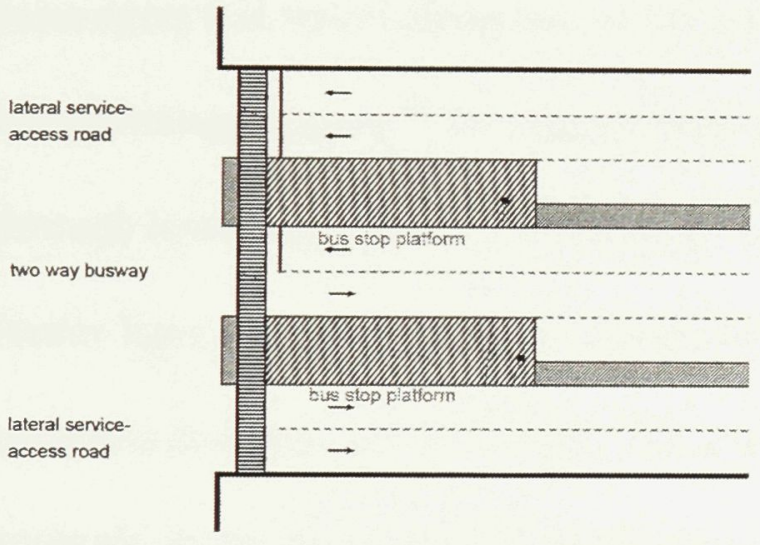

Figure 4.11: Detail Plan of Bus Station.

(Source: Municipal Government of Curitiba. $<\underline{\text { http://www.curitiba.pr.gov.br/ }>\text { ) }}$

To minimize the flow of traffic in a one direction (east-west, north-south)

Curitiba's infrastructural system has four basic categories in defining roads by location and function. First there are the arterial roads that are at the core of the five growth corridors. Second, there are linkage nodes located throughout the system to connect users to outer regions of the growth corridors. Then there are collecting roads that are lined with commercial activity that allow for all sorts of traffic, and lastly, the connecting 
streets that link the structural to the industrial section of the city. All areas of the city are based on these primary categories, but each may be proportionally adjusted to the area density. This structure has created higher residential and commercial density areas with a high availability of public transport.

The first two artery roadways ran North and South, and by 1982 the city had erected all five structural arteries. Complementary to these arteries was the construction of the inter-district and feeder lines of the bus system. In terms of statistics, in 1974 the bus system transported 54,000 passengers a day, and by 1982 the number rose to 400,000 . Today, the system carries over 1.8 million people a day $-75 \%$ of the population of Curitiba. In comparison to North American cities, there are more passengers that travel along one of the arteries than all of Washington D.C.'s mass transportation system. ${ }^{46}$ The feeder lines that connect to the arterial corridors pass through lower density areas to allow for easy access to the outskirts where the secondary feeder lines pass through denser neighborhoods and are connect by the structural corridors at either end of the line. The mass transportation of Curitiba is subway travel network on the street and has grown to accommodate a bus station no further than three blocks from each other in all regions of the city.

The entire public transportation system is simple in its infrastructure, but over the years, the system has become increasingly more dynamic with the addition of numerous bus routes. Today, the system constitutes includes Express Routes, Direct Routes, interdistrict Routes, Feeder Routes, Conventional Routes, City Centre Routes, Neighborhood routes, Night Routes, Special Education Routes and Pro-park Routes. All theses layered 
routes; each created to serve a certain functional purpose but together form a unique structure allowing its urbanization to follow its path. For economic reason, the city of Curitiba does not actually manage the bus system; rather the bus management is contracted out to 10 companies. The city will purchase the buses for the companies, but the companies earn their income by driving and managing the system. The operators of the buses are paid by the number of miles they compile, rather than the number of passengers they carry. This management "allows for a balanced distribution of bus routes and eliminating destructive competition. ${ }^{, 47}$

A successful and dynamic mass transport system cannot sustain its effectiveness if there aren't specially designed stations and busses that fit its organization, and Curitiba's urban planning institute has long been aware of this. Since the late 1970's, Curitiba's administration has held a strong connection with Volvo in developing several bus types that accommodate specifics functions along the city's transport. The most impressive buses used are the express buses that run along the five structural corridors. In the 1980 's, the transportation system utilized buses that had a capacity of 110 passengers, but today, tri-articulated buses, equipped with only fifty-seven seats, hold a capacity of 300 passengers. In an article by the Light Rail Association of America, they state that by making most people stand, rather than supply more seats, it makes the process of entering and exiting the bus much easier on the passengers - taking only 20 seconds at each stop to unload and load. However, this efficient loading and unloading would not be able to function if it were not for the actual bus stations. In many areas of the network, where regular 40-foot buses are used, Curitiba has used a traditional bus shelter however; the 
express routes and the Feeder lines use a specifically designed bus "tube." These innovative-raised tubular shelters, based on subway stations, are designed for efficiency to allow quick simultaneous entry and exit upon the bus's arrival. Before entering the station, fares are paid at a turnstile on either end of the "tube", and passengers are restricted to loading by the front and unloading by the rear. This logical and simple structure may seem conventional today, many metropolises have a similar system however, and Curitiba was at the forefront of developing and using this system. Today, cities such as Ottawa, Canada; Portland, Detroit, Washington DC, Minneapolis, United States; Santiago, Chile amongst many others have modeled their current mass transportation system based on Curitiba.
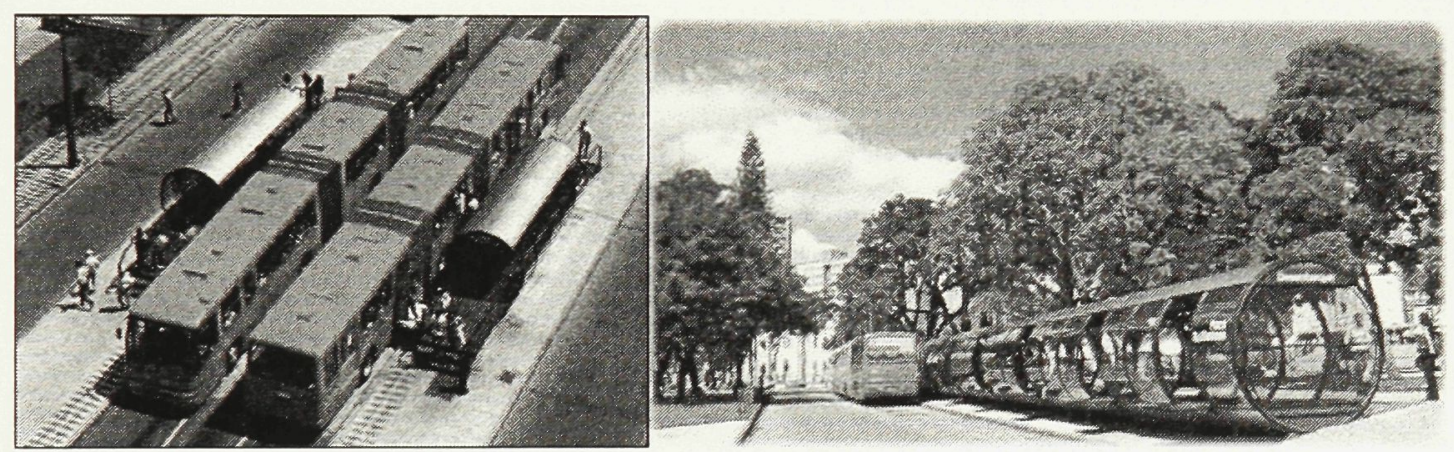

Figure 4.12 \& 4.13: Tube Bus Station. (Source: Municipal Government of Curitiba. $<\underline{\text { http://www.curitiba.pr.gov.br/>) }}$

However, even though the city of Curitiba has been researched by major cities throughout the world, certain cities have found that the system used in Curitiba is unique and is very difficult to apply in North America. For example, Los Angeles officials are continually updating and redeveloping the city road infrastructure and mass transportation, and in their research, they have found that Curitiba's structure has limits in the L.A. current morphology. Firstly, Curitiba has been successful in it s planning because of timing. Mass transportation and growth corridors were built at a time where 
the population and urban infrastructure was small enough to accept such changed. Further, in California, a 270-passenger bus would not be feasible due to the Metropolitan Transportation bylaws. The MTA has implemented a law that only allows a ratio (of total passengers at the peak load point of each line to the number of seats on the bus) to be no more than 1.2:1. The bi-articulated buses have a ration of 4.74: 1 .

Shifting from the embracement of the automobile to a concentration on planning an integrative transit system, Curitiba has resulted in a systemic metropolis allowing the everydayness of the city to be a map and generator of territorialism. "When people understand the importance of the projects, they become involved." 

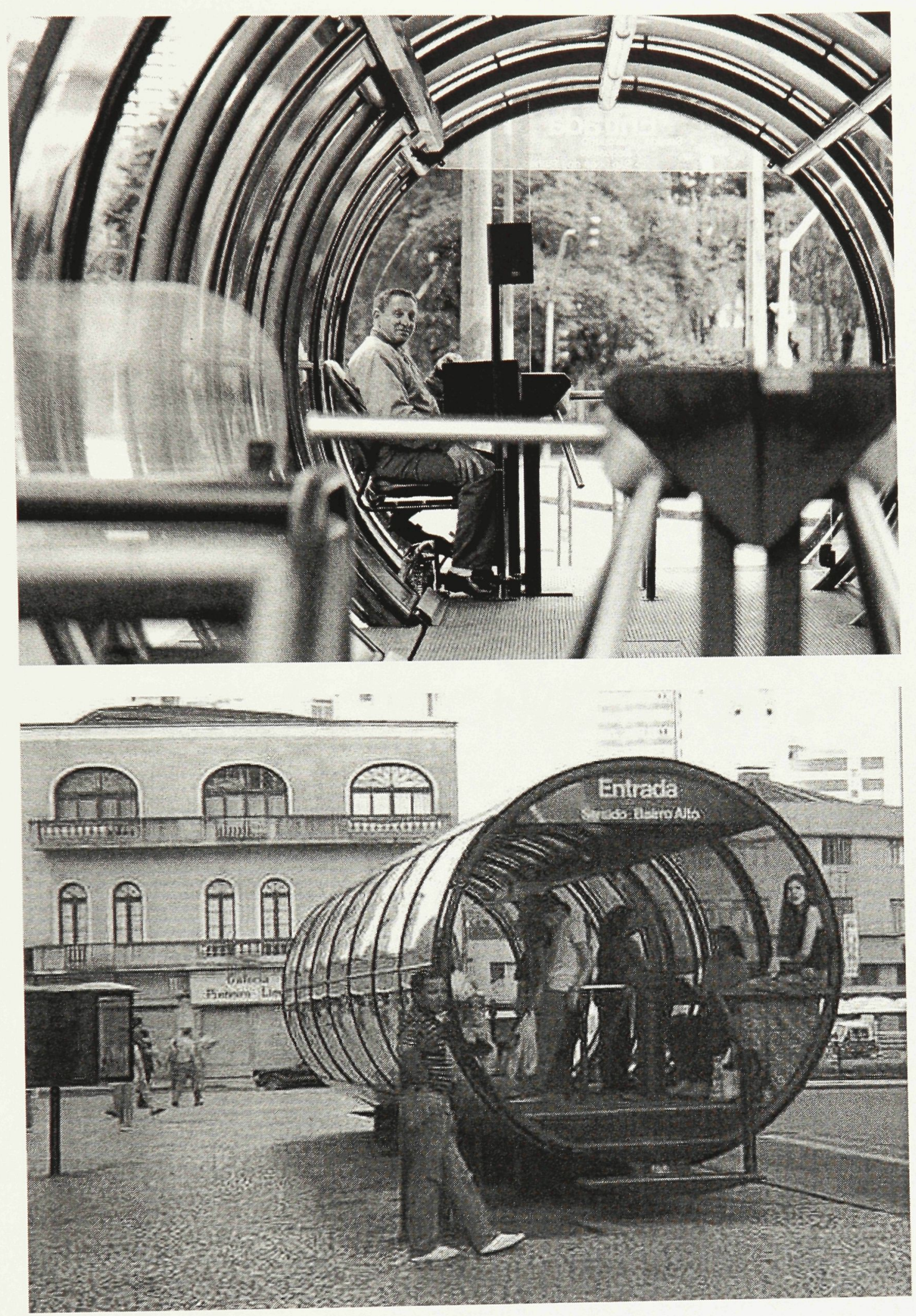

Figure $4.14 \&$ 4.15: Tube Bus Station

(Source: Municipal Government of Curitiba. $<\underline{\text { http } / / \text { www.curitiba.pr.gov.br/>) }}$ 


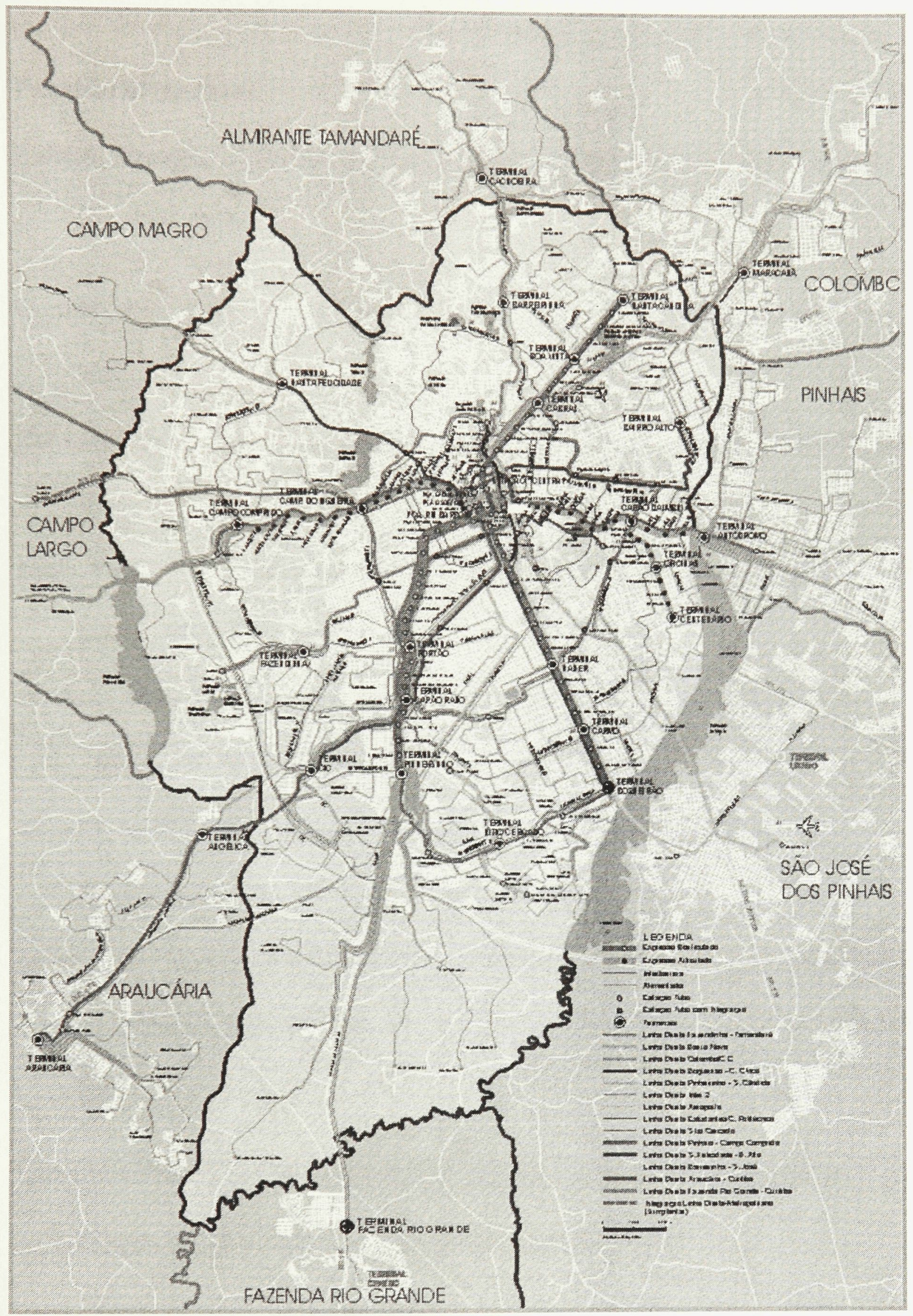

Figure 4.16: Curitiba Transportation Map (2002).

(Source: Municipal Government of Curitiba. <http://www.curitiba.pr.gov.br/>) 


\section{Bibliography}

\section{Practices of the Event}

Bullrich, Francisco. New Directions in Latin American Architecture. New York, NY: G. Braziller. 1969.

Czerniak, Julia. Case: Downsview Park Toronto. New York, NY: Prestel Publishing, 2001.

Deleuze, Gilles. Difference and Repetition. New York, NY: Columbia University Press, 1993.

Healy, Patsy. "On Creating the City as a Collective Resource.” Urban Studies, Vol. 39, No. 10, 1777-1792, 2002.

Koolhaas, Rem. "What ever happened to Urbanism.” S,M,L,XL. New York: NY Monacelli Press, 1994.

Kwinter, Sanford. Architectures of Times: Toward a Theory of The Event in Modernist Culture. Cambridge, Mass.: MIT Press, 2001.

Lerup, Lars. "American Speed, American Distance.” New Urbanism: Michigan Debates on Urbanism: Volume II. ed. Robert Fishman. New York, NY.: Distributed Arts Press. 2005.

Lewis Mumford. The City in History: Its Origins, Its Transformations, and Its

Prospects. New York, NY: Harcourt, Brace \& World, 1961

- - . "What Is a City?" The City Reader, eds. Legates, Richard; Stout, Frederic (New York, NY: Routledge, 1996) 92-96. 
Livesey, Graham. Passages: Explorations of the Contemporary City. Calgary, Alb.: University of Calgary Press, 2004.

Lynch, Kevin. The Image of the City. Cambridge: Mass., MIT Press. 2003. p.46

Massumi, Brian, Ed. The Politics of Everyday Fear. Minneapolis, MN: University of Minnesota Press, 1993.

Rajchman, John. Constructions. Cambridge, Mass.: MIT Press, 1998.

Rykwert, Joseph. The Seduction of Place. The History and Future of the City. Oxford: England. Oxford University Press. 2000.

Sheller, M., Urry, J. "The city and the car." International Journal of Urban and Regional Research, 24, 2000. 737-45.

Tschumi, Bernard. Architecture and Disjunction. Cambridge, Ma., MIT Press. 1994.

- -. Questions of Space: Lectures on Architecture. London: Architectural Association, 1990.

Vacalcanti, Lauro. "When Brazil was Modern: From Rio de Janeiro to Brasilia." Cruelty and Utopia. eds. Jean-Francois Lejeune. New Jersey, NJ: Princeton Architectural Press. 2005.

Waldheim, Charles. "What's Up Downsview?" Canadian Architect Magazine. November 2003. 16-17.

Wise, Macgregor J. "Home: Territory and Identity." Cultural Studies 14 (2), 2000. 295 $-310$. 


\section{Systems Urbanism}

\section{Curitiba, Brazil}

Bullrich, Francisco. New Directions in Latin American Architecture. New York, NY:

George Brazillier, Inc., 1969.

Bray, Thomas. "Can Brazil bus system work in Detroit?" Detroit News Online.

$<\underline{\text { http://detnews.com/2001/editorial/0111/28/a13-353313.htm }>}$

Clarke, Darrell. "Curitiba's Rapid Transit - How Applicable to Los Angeles and Other

U.S. Cities?", LightRail Now.

de Certeau, Michel. The Practice of Everyday Life. Berkeley: University of California Press, 1984.

Knight, Miriam. "Vision + Participation = A City that Works" Community

ConneXion. $<$ http://www.connexion.org/article/09-00/vision.html $>$

Longini, Peter. "Ottawa and elsewhere, Bus Rapid Transit is redefining perceptions of

bus travel." Mass Transit Magazine, march 2001.

$<\mathrm{http}:: /$ www.masstransitmag.com $>$

Massumi, Brian. Parables for the Virtual: Movement, Affect, Sensation. Durnham, NC.:

Duke University Press, 2002

Pierce, Neal R. "Curitiba's World-Class Congestion Cure." Florida Sustainable

Communities Center.

$<$ http://sustainable.state.fl.us/fdi/fscc/news/world/0003/curitiba.htm $>$

Rabinovitch, Jonas. Hoehn, John. "A Sustainable Urban Transportation System: The

"Surface Metro" in Curitiba, Brazil." Working Paper No. 19, $46 \quad$ pages, May 
1995. <http://www.wisc.edu/epat/.energy/.metro/.entire.html>

Vallicelli, Liana. "City of Curitiba, Brazil." Atlantic Planners Institute.

$<\underline{\text { http://www.atlanticplanners.org/whatnew/conf99/curitiba.htm }>}$

Zimmerman, Sam. "Why do Americans like Rail Transit? Look for the Answer in

Washington, Pittsburgh - and Curitiba" Published in Passenger Transport, February 1998

"Curitiba: Public Transit Role Model for Los Angeles?"

$<$ http://real.telebuild.com/ramgen/e-architect/pia/rudc/inourlifetime.rm $>$

"Curitiba and its visionary mayor." The Global Ideas Bank .

$<\underline{\text { http://www.globalideasbank.org/BI/BI-262.HTML }>}$

"Curitiba: An Innovative Bus City." Buses International Dec. 1997.

$<$ http://www.busesintl.com/news/dec97newsletter.html $>$

"Curitiba Urban Transport System." Inter-American Development Bank.

$<$ http://www.iadb.org/exr/doc97/apr/br873e.htm $>$

"Curitiba, Brazil. Three decades of thoughtful city planning." Dismantle.

$<\underline{\text { http://www.dismantle.org/curitiba.htm }>}$

"Curitiba, Brazil. Land Use/Transportation Project \#2." The International Council for

Local Environmental Initiatives.

$<$ http://www.iclei.org/leicomm/lei-025.htm $>$

"Curitiba Reaches High Capacity with 'Busway' System." American Public

Transportation Association.

$<\underline{\text { http://www.apta.com/intnatl/intfocus/curitiba.htm }>}$ 
"Keep It Simple. Begin It Now. Don't Rush to Have All the Answers." MIT Center for Transportation Studies.

$<\underline{\mathrm{http}}$ ://web.mit.edu/cts/news/current/lerner.html $>$

Parana Turismo, Curitiba.

$<$ http://www.pr.gov.br/celepar/seet/prtur/cidades/curitiba/indexi.html $>$

"Rapid Buses--Learning from Brazil, Welborne \& Yaroslavsky Compare Notes." Abel \& Associates. February 1999.

$<\underline{\text { http://www.ablinc.net/mir/archive/feb1999.html }>}$

"Surface Transit Project." Wilshire Center

$<\underline{\text { http://www.wilshirecenter.com/dedicatedbus.htm }}>$

"The Curitiba Experience." Federal Transit Administration

$<\underline{\text { http://www.fta.dot.gov/brt/issues/pt3.html }>}$

"Urban Solutions (Environment, Core ideas, Transportation, Urban Planning)." Prefeitura Municipal de Curitiba $<\underline{\text { http://www.curitiba.pr.gov.br/pmc/ingles/Solucoes/index.html }>}$ 